\title{
Expression of Neurotrophin-3 (NT-3) and Anterograde Axonal Transport of Endogenous NT-3 by Retinal Ganglion Cells in Chick Embryos
}

\author{
Christopher S. von Bartheld and Rafal Butowt \\ Department of Physiology and Cell Biology, University of Nevada School of Medicine, Reno, Nevada 89557
}

\begin{abstract}
Anterograde axonal transport of neurotrophins has been demonstrated recently, but to date such transport has only been shown for brain-derived neurotrophic factor and no other endogenous neurotrophin. Endogenous neurotrophin-3 (NT-3) protein is present in the ganglion cell layer of the chicken retina, as well as the superficial layers of the optic tectum. NT-3 immunolabel in these tectal layers is largely reduced or abolished after treatment of the eye with colchicine or monensin, demonstrating that endogenous NT-3 is transported to the optic tectum by retinal ganglion cells (RGCs). Reverse transcription-PCR analysis of RGCs purified to $100 \%$ shows that RGCs, but not tectal cells, express NT-3 mRNA. Blockade of the intercellular transfer of NT-3 within the retina does not reduce the anterograde transport of endogenous NT-3 to the tectum, indicating that a major fraction of the anterogradely
\end{abstract}

Neurotrophins are well known as target-derived, retrograde survival-promoting molecules that require the transport of the neurotrophic factor from the axon terminus to the cell body (Hendry et al., 1974; Johnson et al., 1978; Purves, 1988; Barde, 1989; Oppenheim, 1996). Neurotrophins are also important regulators of neuronal differentiation and synaptic plasticity (Snider, 1994; Thoenen, 1995). Recent studies have shown that neurotrophins can be transported anterogradely along axons (von Bartheld et al., 1996a; Zhou and Rush, 1996; Altar et al., 1997; Conner et al., 1997, 1998; Heymach and Barres, 1997; Johnson et al., 1997; Michael et al., 1997; Smith et al., 1997; Yan et al., 1997; Altar and DiStefano, 1998). Such anterograde transport may function to provide trophic support from afferents (Linden, 1994; von Bartheld et al., 1996a; Altar et al., 1997), to mediate fast, local effects at synaptic sites (Lohof et al., 1993; Kang and Schuman, 1995; Thoenen, 1995; Berninger and Poo, 1996), or to regulate dendritic growth, neuronal cytoarchitecture, and phenotypes

\footnotetext{
Received Aug. 19, 1999; revised Nov. 3, 1999; accepted Nov. 5, 1999.

The work was supported by National Institutes of Health Grants HD 29177 and NS 35931. This work is dedicated to the memory of Dietrich L. Meyer (1947-1999). Hybridoma cell lines for this study were kindly provided by I. Bartke (Boehringer Mannheim) (NT-3 antibody) and H. Tanaka (p75 antibody M7412). Monoclonal antibodies were provided by P. Jeffrey (anti-Thy1); polyclonal antibodies were provided by R. Rush (anti-NT-3), K. Bailey and Y. Barde (anti-BDNF), L. Reichardt, D. Clary, and F. Lefcort (anti-trkB and -trkC), and B. Hempstead (anti-truncated trkC); chicken NT-3 cDNA was provided by P. Maisonpierre and G. Yancopoulos (Regeneron); and human recombinant BDNF, NT-3, and NT-4 were provided by R. Lindsay (Regeneron). We thank Y. Kinoshita and K.-H. Herzog for help with antibody collection and purification and M. Bothwell for logistic support in the initial phases of this project.

Correspondence should be addressed to Dr. Christopher von Bartheld, Department of Physiology and Cell Biology, Mailstop 352, University of Nevada School of Medicine, Reno, NV 89557. E-mail: chrisvb@physio.unr.edu.

Copyright (C) 2000 Society for Neuroscience $0270-6474 / 00 / 200736-13 \$ 15.00 / 0$
}

transported NT-3 is produced by RGCs rather than taken up from other retinal cells. Immunolabel for the neurotrophin receptor p75, but not trkB or trkC, in the superficial tectum coincides with the NT-3 label. The p75 label in the neuropil of superficial tectal layers is largely reduced or eliminated by injection of monensin in the eye, indicating that p75 protein is exported along RGC axons to the retinotectal terminals and may act as a neurotrophin carrier. These results show that NT-3 is produced by RGCs and that some of this NT-3 is transported anterogradely along the axons to the superficial layers of the tectum, possibly to regulate the survival, synapse formation, or dendritic growth of tectal neurons.

Key words: anterograde transport; NT-3; BDNF; retina; optic tectum; p75 neurotrophin receptor; neurotrophic factor; visual system; RT-PCR
(Purves, 1988; Altar et al., 1997; McAllister et al., 1999). Brainderived neurotrophic factor (BDNF) is stored in axon terminals (Conner et al., 1997; Fawcett et al., 1997; Michael et al., 1997) and may be released into the synaptic cleft to activate postsynaptic neurotrophin (trk) receptors (Levine et al., 1995; Wu et al., 1996).

Endogenous BDNF is transported anterogradely in several systems (Zhou and Rush, 1996; Altar et al., 1997; Conner et al., 1997; Smith et al., 1997; Yan et al., 1997), but anterograde transport of other endogenous neurotrophins has not been demonstrated. Exogenous neurotrophin-3 (NT-3) is transported anterogradely by retinal ganglion cells (RGCs), is released from the terminals, and is taken up by the dendrites of second-order target cells in the optic tectum of chick embryos (von Bartheld et al., 1996a), but this study did not examine transport of endogenous NT-3. Because current research in this field focuses on BDNF, it is of interest to know whether other neurotrophins may function as anterograde messengers. The retinotectal pathway is a model system in which the anterograde transport and release of neurotrophins can be uniquely quantified (Baeten et al., 1997; Wang et al., 1999). This pathway allows us to determine whether anterograde transport characteristics of endogenous and exogenous neurotrophins are similar or whether they may differ and which receptors may be involved in axonal transport.

Here we show that RGCs produce NT-3, that endogenous NT-3 is transported by RGCs in the same manner as exogenous NT-3, and that NT-3 transport and transport of the p75 neurotrophin receptor coincide. Our study further provides evidence that a major fraction of the transported endogenous NT-3 is expressed by the RGCs themselves, rather than taken up from other cells in the retina. The analysis of the contributions of intrinsic and extrinsic sources of the p75 neurotrophin receptor in 
the superficial layers of the optic tectum provides evidence that this receptor is predominantly derived from the retina.

Parts of this paper have been published previously in abstract form (von Bartheld, 1997).

\section{MATERIALS AND METHODS}

Sources of materials. The hybridoma cell line (1D53B2) producing antibody to NT-3 (termed NT-3 mAB) (Gaese et al., 1994) was provided by Boehringer Mannheim (courtesy of Ilse Bartke). Polyclonal antibody to NT-3 was a kind gift of Robert Rush (Flinders University, Adelaide, Australia) (Zhou and Rush, 1993). Monoclonal antibodies to chicken p75 were obtained from Hideaki Tanaka (Kumamoto University, Kumamoto, Japan) and to Thy1 were from Peter Jeffrey (French and Jeffrey, 1986). Polyclonal antibody to BDNF was from Karen Bailey and Yves Barde (Martinsried, Germany). Polyclonal antibody to trkB and trkC (against the extracellular domain) was from Louis Reichardt, Frances Lefcort, and Doug Clary (Lefcort et al., 1996; von Bartheld et al., 1996b). Polyclonal antibody to truncated trkC was from Barbara Hempstead (Cornell, NY). Chicken NT-3 cDNA was a gift of George Yancopoulos (Regeneron, Tarrytown, NY). Human recombinant BDNF, NT-3, and NT-4 were provided by Ron Lindsay (Regeneron). Mouse NGF was a kind gift of Mark Bothwell (Seattle, WA). Colchicine and monensin were from Sigma (St. Louis, MO); pertussis toxin was from List Biologic (Campbell, CA). Chicken eggs were obtained from $\mathrm{H}+\mathrm{N}$ (Redmond, WA) or California Golden Eggs (Sacramento, CA) and were incubated in humidified incubators at $37.5-38^{\circ} \mathrm{C}$. Approximately 450 chicken eggs were used. The ages of chick embryos were verified at the time of death according to the method of Hamburger and Hamilton (1951). The terminology of LaVail and Cowan (1971) was used for the optic tectum of the embryonic chicken. Experimental procedures were conducted in compliance with the Policy on the Use of Animals in Neuroscience Research and were approved by the local animal care committee.

Hybridoma culturing. NT-3 mAB hybridoma cells (United States Department of Agriculture permit \#40032) were grown in $25 \mathrm{ml}$ Corning flasks containing RPMI, 2 mM glutamine, 1 mM Na-pyruvate, $1 \%$ nonessential amino acids, and $2-5 \%$ fetal bovine serum. Supernatant was harvested every $2-6$ weeks; the antibody was concentrated by precipitation with ammonium sulfate, dialyzed overnight, purified on a Bio-Rad Protein A (Affi-Gel) column, dialyzed again overnight, and concentrated by membrane filtration using Ultrafree MC membrane tubes (Millipore, Bedford, MA). The final concentration of the antibody was determined in a spectrophotometer. Aliquots were stored at $-80^{\circ} \mathrm{C}$. Samples were run on $10 \%$ SDS-PAGE and stained with Coomassie blue, revealing a major band at $\sim 50 \mathrm{kDa}$, as expected for IgG. The supernatant from p75 (M7412) $\mathrm{mAB}$ hybridoma cells was frozen in aliquots at $-80^{\circ} \mathrm{C}$ and used at a dilution of 1:2 for immunocytochemistry (von Bartheld et al., 1995).

Dot blots. A dilution series of 100-0.05 ng of NGF, BDNF, NT-3, and NT-4 was pipetted onto filter paper, dried, and incubated after washes with $2 \%$ normal horse serum in 1 or $20 \mu \mathrm{g} / \mathrm{ml} \mathrm{NT}-3 \mathrm{mAB}$. The blots were incubated with biotinylated secondary antibodies followed by streptavidin-conjugated horseradish peroxidase (Vector Laboratories, Burlingame, $\mathrm{CA}$ ) and reacted with diaminobenzidine (DAB). The sensitivity of the antibody was evaluated by visual inspection.

Immunocytochemistry. After anesthesia with Nembutal, chicken embryos were perfused transcardially with $4 \%$ paraformaldehyde (PFA) in PBS, and tecta and retinae were post-fixed in the same fixative for $16 \mathrm{hr}$ at $4^{\circ} \mathrm{C}$. After sucrose impregnation of the tissues $(30 \%$ sucrose for $24 \mathrm{hr}$ at $4^{\circ} \mathrm{C}$ ), $18 \mu \mathrm{m}$ cryosections were thawed on gelatin-coated slides. Sections through the tectum were cut at $30 \mu \mathrm{m}$ and processed free-floating. Brain sections were cut in the transverse plane. Immunostaining was performed according to the Vector protocol (Vector Laboratories) with some modifications (Zhou et al., 1994). In brief, some sections were treated with three washes of $50 \%$ ethanol and then were incubated with diluted blocking serum (5-10\% normal goat or horse serum) for $30 \mathrm{~min}$ at room temperature, followed by three washes with PBS and $0.1 \%$ Triton X-100 and incubation overnight with primary antisera. Primary antibodies were applied at the following dilutions or concentrations: NT-3 mAB, $20 \mu \mathrm{g} / \mathrm{ml}$; p75 mAB (7412, tissue culture supernatant), diluted 1:2; NT-3 polyclonal antibody (pAB), $1 \mu \mathrm{g} / \mathrm{ml}$; BDNF pAB, diluted 1:100; trkB pAB, $1 \mu \mathrm{g} / \mathrm{ml}$; trkC pAB, $1 \mu \mathrm{g} / \mathrm{ml}$; and truncated trkC $\mathrm{pAB}$, diluted 1:500 or 1:1000. Sections treated with polyclonal antibodies (NT-3, BDNF, trkB, or trkC) as the primary antibodies were rinsed three times and incubated with a biotinylated goat anti-rabbit antibody diluted in blocking serum. For sections treated with monoclonal antibodies
(NT-3 mAB and M7412 p75 mAB) as the primary antibodies, a biotinylated horse anti-mouse or goat anti-mouse antibody was used. After three washes, we applied ABC reagent or horseradish peroxidaseconjugated streptavidin (1:500; Zymed, South San Francisco, CA) for 30 min, rinsed three times, and preincubated for $10 \mathrm{~min}$ in $0.1 \% \mathrm{DAB}$ in $0.04 \%$ nickel ammonium sulfate in Tris-buffered saline (100 mM Tris, $\mathrm{pH}$ 7.4 , and $150 \mathrm{~mm} \mathrm{NaCl}$ ) until the reaction product was clearly visible. Slides were rinsed in water, dehydrated, and coverslipped. Some sections were lightly counterstained with thionin. Control sections were processed with omission of the primary antibody, with normal rabbit IgG as the primary antibody, or after preabsorption of the primary antibody with $10^{-4}-10^{-5}$ M NT-3 peptide for $24 \mathrm{hr}$ at $4^{\circ} \mathrm{C}$.

Radio-iodination, intraocular injections, and autoradiography. Human recombinant NT-3 and NT-3 mAB were iodinated with lactoperoxidase as described (Vale and Shooter, 1985; von Bartheld, 1998b). Na ${ }^{125}$ I was purchased from Dupont NEN (Boston, MA). Incorporations were 79.790.3\% (NT-3) and $84.9 \%$ (NT-3 mAB), and the specific activities were $70.6-129.4 \mathrm{cpm} / \mathrm{pg}$ of NT-3 and $116.6 \mathrm{cpm} / \mathrm{pg}$ of NT-3 mAB. Free iodide was removed from the NT-3 preparation when the incorporation was less than $90 \%$. Iodinated NT-3 migrated in $15 \%$ SDS-PAGE as a single band at $\sim 14 \mathrm{kDa}$ and was transported in a receptor-mediated manner (von Bartheld et al., 1996a). Cold blocking NT-3 antibody (mAB; 0.4-20 $\mu \mathrm{g}$ ) was injected in one eye of 14- to 15 -d-old chick embryos, followed by co-injection of $0.4-10 \mu \mathrm{g}$ of antibody with $50-100 \mathrm{ng}$ of ${ }^{125} \mathrm{I}-\mathrm{NT}-31 \mathrm{hr}$ later in the same eye. Control embryos received the higher dose of a control IgG (192 IgG, a rat-specific monoclonal antibody) (Chandler et al., 1984; Taniuchi and Johnson, 1985) at the same concentration, followed by an injection of 50-100 ng of ${ }^{125}$ I-NT-3 in the same eye. Two to sixty-four hours (usually $20 \mathrm{hr}$ ) later, the embryos were anesthetized with Nembutal, perfused with 4\% PFA, staged, and post-fixed. The amount of radioactivity in the dissected eyes and midbrains [embryonic day 15 (E15)-E17] was measured in a gamma counter. The ratios of the activity in the midbrain/eye were determined for each animal and averaged for the different treatment groups (normal animals, intraocular control antibody, and intraocular blocking NT-3 antibody). SEs were calculated, and the data were plotted as a function of the doses injected. The brains and the eyes were embedded in paraffin, four series of sections $(10 \mu \mathrm{m}$ thickness) through the midbrain at the level of the isthmo-optic nucleus were collected on glass slides and exposed on x-ray film for 2-5 d, and the sections were coated with NTB-2 emulsion (Eastman Kodak, Rochester, NY). Sections were exposed for $3-8$ weeks at $4^{\circ} \mathrm{C}$ and were lightly counterstained with thionin after development and coverslipped. After injections of iodinated proteins into the retina or into the tectum, the amount of radioactivity in the eyes was measured in a gamma counter. Autoradiographic silver grains were counted using $40 \times$ or $100 \times$ objectives. To determine whether the NT-3 mAB was transported from the retina to the optic tectum, we injected $350 \mathrm{ng}$ of ${ }^{125} \mathrm{I}-\mathrm{NT}-3 \mathrm{mAB}$ into the eye of a 15-d-old chick embryo and processed the brain $21 \mathrm{hr}$ later for gamma counting and emulsion autoradiography as described.

Other injection procedures. Colchicine $(0.7 \mu \mathrm{g})$ was dissolved in PBS and was injected in a volume of $5 \mu \mathrm{l}$ in the vitreous. Monensin $(9 \mu \mathrm{g})$ was dissolved in ethanol and injected in a volume of 2-4 $\mu$ l. Pertussis toxin $(0.2 \mu \mathrm{g})$ was dissolved in PBS and injected in a volume of $7 \mu \mathrm{l}$. Antibodies (0.4-22 $\mu \mathrm{g}$ of mAB NT-3 or irrelevant IgG) were diluted in PBS and injected in volumes of $4-10 \mu \mathrm{l}$ in the vitreous. Solution with vehicle only in the same volume was injected in the control eye. The eyes were embedded in paraffin, sectioned at $10 \mu \mathrm{m}$, and stained with thionin, and the frequency of pyknotic cells was compared between the ipsilateral and the contralateral retina.

Injections into the tectum were made through the skull as described previously (von Bartheld et al., 1995). Radio-iodinated NT-3 was injected into the optic tectum of 20- to 21-d-old chick embryos by using disposable syringes (von Bartheld, 1998b). After $20 \mathrm{hr}$ of survival, the animals were anesthetized and perfused transcardially with $4 \%$ PFA. Midbrains containing 100,000-200,000 cpm were counted after dehydration and dissected for further localization of the counts, and the retinae were dissected, dehydrated, and counted in the gamma counter.

NT-3 in situ hybridization. A chicken NT-3 cDNA (Maisonpierre et al., 1992) (courtesy of P. Maisonpierre and G. Yancopoulos, Regeneron) was subcloned into pGEM. Single-stranded riboprobes (644 bp) were labeled with ${ }^{35}$ S-UTP and used for hybridization as described (von Bartheld et al., 1991, 1996a). Animals at E13 and E15/E16 were anesthetized and perfused with $4 \%$ PFA. The eyes were dehydrated, embedded in paraffin, and sectioned at $10 \mu \mathrm{m}$. Sections through the brain and retina were collected on silane-coated glass slides. Adjacent sections were hybridized 
with a sense control probe. Hybridization conditions were as described previously (von Bartheld et al., 1991). Emulsion-coated sections were exposed for 14-28 d, developed, and lightly counterstained with thionin.

$R G C$ purification. RGCs were purified by a combination of retrograde labeling with DiI, immunopanning with Thy1, and microaspiration of labeled immunopanned cells for molecular analysis (Butowt et al., 2000). Chick embryos or hatchling chicks were anesthetized by intramuscular injection of Nembutal $(50 \mathrm{mg} / \mathrm{kg}$ of body weight), and 2-4 $\mu \mathrm{l}$ of DiI was injected into the optic nerve $\sim 2 \mathrm{~mm}$ proximal to its exit from the eye. Fifteen hours later, the animals were killed by an overdose of Nembutal, and the retina was dissected and dissociated with trypsin. It was verified by cryosectioning (von Bartheld et al., 1990; Butowt et al., 2000) that DiI label in the retina was restricted to cells in the ganglion cell layer and displaced ganglion cells in the inner nuclear layer (INL) (Reiner et al., 1979). For immunopanning, we used mouse monoclonal IgG SB1-20.11 against chicken Thy1 (French and Jeffrey, 1986) as the primary antibody and affinity-purified goat anti-mouse IgG (M8645; Sigma) as the secondary antibody. Plates with adhering RGCs were placed on an inverted microscope (Nikon TE200) equipped with phase-contrast optics and epifluorescence. Glass capillaries (pulled from glass borosilicate capillaries to a final average diameter ranging from 20 to $30 \mu \mathrm{m}$ ) were positioned with a micromanipulator, and viable (phase-bright) cells with intense fluorescence were collected in the pipette tip by exerting negative pressure. Up to 500 fluorescent cells were collected in one micropipette, transferred to sterile RNase-free Eppendorf microfuge tubes, and immediately frozen at $-80^{\circ} \mathrm{C}$.

$R N A$ isolation and reverse transcription-PCR. Total RNA was isolated from 600 or 1000 viable purified RGCs, the same numbers of random retinal cells, or 1000-2000 random cells obtained from the superficial layers of the optic tectum of the same animals (E19-E20 embryos). RNA was extracted with Trizol reagent (Life Technologies, Rockville, MD) according to the manufacturer's recommended procedure. Before the final RNA precipitation, $2.5 \mu \mathrm{g}$ of RNase-free yeast tRNA (Life Technologies) was added to the sample as a carrier. Total RNA samples were digested with $0.5 \mathrm{U}$ of RNase-free DNase I (Ambion, Inc., Austin, TX) for $20 \mathrm{~min}$ at $37^{\circ} \mathrm{C}$ followed by heating to $80^{\circ} \mathrm{C}$ for $6 \mathrm{~min}$. Reverse transcription (RT) was performed by using RETROscript reagents (Ambion, Inc.) with $5 \mu \mathrm{M}$ random decamer primers and $100 \mathrm{U}$ of MMLV RT in a buffer containing $50 \mathrm{~mm}$ Tris- $\mathrm{HCl}, \mathrm{pH} 8.3,75 \mathrm{~mm} \mathrm{KCl,} 3 \mathrm{~mm} \mathrm{MgCl}_{2}$, and $3 \mathrm{~mm}$ DTT in a total volume of $20 \mu \mathrm{l}$ at $44^{\circ} \mathrm{C}$ for $60 \mathrm{~min}$. Whole cDNA was digested with HinfI (Promega, Madison, WI; to avoid any genomic DNA contamination) at $37^{\circ} \mathrm{C}$ for $20 \mathrm{~min}$. After the RT step, two separate PCR reactions were performed, one for abundant $18 \mathrm{~S}$ rRNA (primers: forward, 5'TCAAGAACGAAAGTCGGAGG, and reverse, 5'GGACATCTAAGGGCATCACA; product size, 488 bp; 27 cycles, $94^{\circ} \mathrm{C}$ for $35 \mathrm{sec}, 58^{\circ} \mathrm{C}$ for $40 \mathrm{sec}$, and $72^{\circ} \mathrm{C}$ for $45 \mathrm{sec}$ ) and a second one for NT-3 (primers: forward, 5'CTTACAGGTGAACAAGGTGATGTCC, bp 69-93, and reverse 5'CACGCAGGAGGTGTCTATTCTTATC, bp 828-804; product size, $758 \mathrm{bp} ; 30$ cycles, $94^{\circ} \mathrm{C}$ for $30 \mathrm{sec}, 55^{\circ} \mathrm{C}$ for $45 \mathrm{sec}$, and $72^{\circ} \mathrm{C}$ for $55 \mathrm{sec}$ ). NT-3 primers (Life Technologies) were designed by using Mac-Vector software, and $18 \mathrm{~S}$ rRNA primers were purchased from commercial sources (Ambion, Inc.). The final PCR volume of $50 \mu \mathrm{l}$ contained $5 \mu \mathrm{l}$ of cDNA, each primer at $0.4 \mu \mathrm{M}, 0.2 \mathrm{~mm}$ dNTP, $1.5 \mathrm{mM} \mathrm{MgCl}_{2}$, and $2.5 \mathrm{U}$ of Taq polymerase (Life Technologies) in standard PCR buffer (Life Technologies). For NT-3, the second "nested" PCR cycle was performed by using $0.3 \mu \mathrm{l}$ of the first PCR product (primers: forward, 5'TGGATCAAAGGAGTTTGCCAGA, bp 149-170, and reverse, 5'CTTAACTGGAGAGTGGCCTGTT, bp 648627; product size, $498 \mathrm{bp} ; 27$ cycles, $94^{\circ} \mathrm{C}$ for $25 \mathrm{sec}, 48^{\circ} \mathrm{C}$ for $35 \mathrm{sec}$, and $72^{\circ} \mathrm{C}$ for $45 \mathrm{sec}$ ). Control experiments were performed without MMLV RT for each set of primers. RT-PCR products for NT-3 were purified by using the Qiaquick PCR purification kit (Qiagen, Santa Clarita, CA) and directly sequenced by using an ABI Prism 310 machine. Sequencing results were compared with the published chicken NT-3 cDNA sequence available in the database (Maisonpierre et al., 1992). PCR products were separated by $1.2 \%$ agarose gel electrophoresis containing $0.5 \mu \mathrm{g} / \mathrm{ml}$ ethidium bromide in standard TBE buffer, $\mathrm{pH}$ 8.4. Bands were documented with a Gel-Doc 2000 system (Bio-Rad, Hercules, CA).

Quantification of cell death and thickness of layers in the tectum. The number of pyknotic profiles in the stratum griseum centrale (SGC) layer of the optic tectum of chick embryos was quantified after injections of blocking NT-3 mAB (2-22 $\mu \mathrm{g})$ to assess effects of anterogradely transported NT-3. Cell death was also quantified after injections of the eye with pertussis toxins to verify the success of these injections. In short, $3 \mathrm{~d}$ after intraocular injections, chick embryos were decapitated, heads were fixed in Methacarns fixative, and the brains were dissected from the skull. In the case with injections of pertussis toxin, the eyes required PFA fixation for subsequent NT-3 immunocytochemistry; therefore, the animals were anesthetized with Nembutal, the brains were dissected out and fixed in Methacarns, and the rest of the body was transcardially perfused with $4 \%$ PFA. Embryos were staged according to the method of Hamburger and Hamilton (1951), and the brains were embedded in paraffin. Pyknotic cells were quantified as described (Catsicas et al., 1992; von Bartheld et al., 1996a). The brains were serially sectioned at $10 \mu \mathrm{m}$, a one in four series was collected on slides and stained with thionin, and every neuronal profile containing a pyknotic nucleus was counted in the ipsilateral and contralateral SGC in sections through the caudal part of the tectum at the level of the isthmo-optic nucleus. Profiles were counted blind as to the treatment group. Unbiased stereological methods were not used for these experiments. The data were used only to establish the success of the intraocular injection (pertussis toxin) or to determine whether cell death in the tectum was significantly enhanced by the treatment of the eye with antibodies. Because the structures being counted do not change in shape, size, or orientation between the treatment groups, any systematic bias in the estimation of population size should cancel out of the calculation. After injections of either $0.7 \mu \mathrm{g}$ of colchicine or $9 \mu \mathrm{g}$ of monensin or daily injections of anti-NT-3 mAB in the eye, the thickness of the tectal layers containing retinal ganglion cell axons and terminals [stratum opticum (SO) and stratum griseum et fibrosum superficiale (SGFSa-f)] was measured and compared between the contralateral and the ipsilateral tectum (internal control). The mean percent difference in thickness was calculated from six to seven brains, and statistical significance was determined by $t$ test.

DiI tracing after injections of colchicine or monensin. In five embryos injected with either colchicine or monensin in one eye and vehicle in the other eye, DiI crystals were subsequently applied to the optic tract or superficial layer of the optic tecta of PFA-fixed brains (Godement et al., 1987; von Bartheld et al., 1990), and the brains were kept in PFA for $20-25 \mathrm{~d}$ at $37^{\circ} \mathrm{C}$. The brains were sectioned at $100 \mu \mathrm{m}$ on a vibratome, and sections through the tectum were collected on gelatin-coated slides. The sections were immediately coverslipped in aqueous mounting medium and examined on a Nikon Eclipse microscope for fluorescence, and representative sections were photographed with T-MAX 400 film.

\section{RESULTS}

\section{Specificity and sensitivity of the NT-3 mAB}

The sensitivity and specificity of the monoclonal NT-3 antibody were tested in a dot blot assay. NT-3 antibody detected 1-5 ng of $\mathrm{NT}-3$, and there was no cross-reactivity with BDNF or NGF, even at 20-100 times higher concentrations (Fig. $1 A$ ). Therefore, the monoclonal NT-3 antibody is as sensitive and specific as other neurotrophin antibodies that have been characterized previously (Zhou and Rush, 1993; Anderson et al., 1995).

\section{NT-3 immunoreactivity in the retina}

Sections collected on slides and free-floating sections through the retina of 14- to 16-d-old chick embryos were immunolabeled with $\mathrm{pABs}$ and $\mathrm{mABs}$ against NT-3. Free-floating retinal sections tended to have higher nonspecific background, and our analysis therefore focused on sections reacted on the slide. Both antibodies showed a similar pattern. The large majority if not all cells in the ganglion cell layer (GCL) were immunolabeled (Fig. 1C). In addition, many cells in the inner half of the INL were labeled faintly or moderately (Fig. $1 C$ ), consistent with a previous report (Das et al., 1997). In some sections, two to three thin bands of immunolabel were visible in the outer plexiform layer (OPL; Fig. $1 C$ ), but this banding was not consistently seen. When the primary antibody was omitted, there was no cellular or neuropil label (Fig. 1B). When 250-500 ng of human recombinant NT-3 was injected in the chick eye, $20 \mathrm{hr}$ later, sections through the retina showed greatly increased immunolabel for NT-3 in the GCL and inner plexiform layer (IPL) compared with the vehicle-injected or noninjected control retina (Fig. $1 B-D$ ). No difference in the 

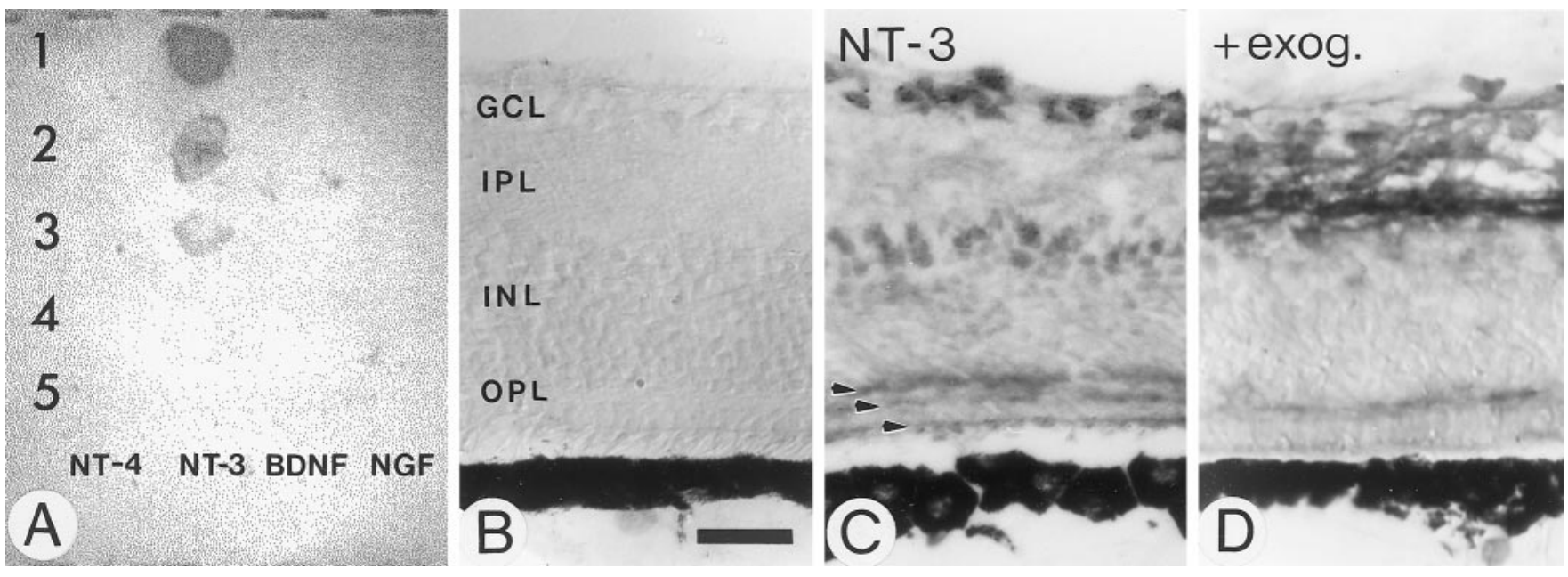

Figure 1. Specificity and sensitivity of the monoclonal NT-3 antibody (mAB 1D53B2). A, Dot blot of NT-3 mAB showing its sensitivity and specificity for NT-3 compared with NGF, BDNF, and NT-4. The antibody detected $<5$ ng of NT-3 and did not cross-react with 100 ng of NGF, BDNF, or NT-4. Dilutions are $100 \mathrm{ng}$ (row 1), $10 \mathrm{ng}$ (row 2), $5 \mathrm{ng}$ (row 3), $1 \mathrm{ng}$ (row 4), and $0.5 \mathrm{ng}$ (row 5). B, Section through the retina from a 16-d-old chick embryo. A control section in which the primary antibody was omitted is shown. The layers of the retina are indicated. $C$, NT-3 immunolabel of cryosection near-adjacent to the one in $B$. Note the cellular label in the GCL and the inner half of the INL. Several bands (arrowheads) are immunolabeled in the OPL, but not all of these bands were seen consistently. $D$, NT-3 immunolabel of a retina that had been injected with 500 ng of human recombinant NT-3 $20 \mathrm{hr}$ before death. Note the distribution of exogenous NT-3 (+exog.) in the IPL. Scale bar: $B-D, 20 \mu \mathrm{m}$.

intensity of the immunolabel was detected between the ipsilateral and contralateral optic tectum in these animals (data not shown).

\section{NT-3 immunoreactivity in the tectum}

RGCs can transport exogenous NT-3 anterogradely to the optic tectum (von Bartheld et al., 1996a) where it accumulates in the superficial tectal layers SO and SGFSa-d (Fig. 2A). Sections through the normal tectum show a distinct band of NT-3 immunolabel in the same layers (SO-SGFSa-d; Fig. 2B). The label was most intense in the SGFSd and less pronounced in the SGFSc. The same pattern was seen in sections processed with either the monoclonal or the polyclonal antibodies (Fig. 2B,D). There was no label when the primary antibody was preabsorbed or omitted (Fig. 2C). The label in the superficial tectal layers was seen consistently in free-floating sections and occasionally could also be observed in sections reacted on the slide. In addition to the neuropil label in SO-SGFSa-d, many cell bodies were labeled in the SGC (Fig. 2B,D). To determine the percentage of SGC neurons labeled with the NT-3 antibody, some sections through the tectum were counterstained with thionin after immunolabeling. Approximately $70 \%$ of the cells in the SGC were immunolabeled. Because the SGFSd is the predominant layer in which retinal axons terminate (Fig. $2 F$ ) (Crossland et al., 1975; Acheson et al., 1984), the NT-3 immunolabel in this neuropil is consistent with the notion that RGCs may transport endogenous NT-3 to their axon terminals.

\section{Reduced NT-3 immunoreactivity with colchicine or monensin: evidence of anterograde transport of endogenous NT-3}

To determine whether the endogenous NT-3 immunoreactivity in the superficial layers of the optic tectum was derived from the retina or from other sources in the brain, 16- to 17 -d-old chick embryos were injected in one eye with either colchicine $(0.7 \mu \mathrm{g})$ or monensin $(9 \mu \mathrm{g})$. These doses entirely prevent anterograde transport of exogenous NT-3 (von Bartheld et al., 1996a) (C. S. von Bartheld, unpublished observations). When examined $48 \mathrm{hr}$ later (colchicine experiments) or 30-50 hr later (monensin ex- periments), the immunoreactivity in the superficial layers of the optic tectum on the contralateral side was much reduced or abolished (Fig. 2E), whereas that on the vehicle-treated ipsilateral (control) side was unaffected (Fig. 2D). Sections immunolabeled with either the monoclonal or the polyclonal NT-3 antibodies yielded similar results. The cell body labeling in the SGC layer was not visibly affected by the colchicine or monensin treatment in the eye. These data show that the source of the NT-3 immunoreactivity in the superficial tectal layers was in the retina, demonstrating that RGCs transport endogenous NT-3 to the tectum.

\section{Loss of NT-3 from the tectum: lack of transport or loss because of retinal fiber degeneration?}

Loss of NT-3 protein from the superficial tectum may be caused by the elimination of anterograde transport, but it may also be caused by the degeneration of retinotectal terminals and fibers as a consequence of toxin treatment (chemical axotomy) (Lunn et al., 1990). To determine whether the retinal axon terminals in the tectum were maintained after colchicine or monensin treatment of the eye, we attempted to label these fibers in fixed tissue by the postmortem DiI technique (Godement et al., 1987). DiI label was readily obtained in the SGFSa-f layers on the control side (Fig. $3 A$ ), but not in the experimental tectum where a diffuse DiIlabeling pattern was confined to the SO layer (Fig. 3B). In addition, after either axotomy or monensin or colchicine treatment in the eye, the SO and SGFSa-f layers were significantly reduced in thickness (Figs. 3C-E), and the number of pyknotic cells in the GCL of the injected retina was increased compared with that of control retinae (data not shown). These data are consistent with the notion that chemical axotomy induces terminal fiber degeneration and membrane disintegration of distal axons. We conclude that both the elimination of anterograde axonal transport and the ensuing degeneration of axon terminals contribute to the loss of NT-3 protein seen in the retinotectal projection after colchicine or monensin treatment. 


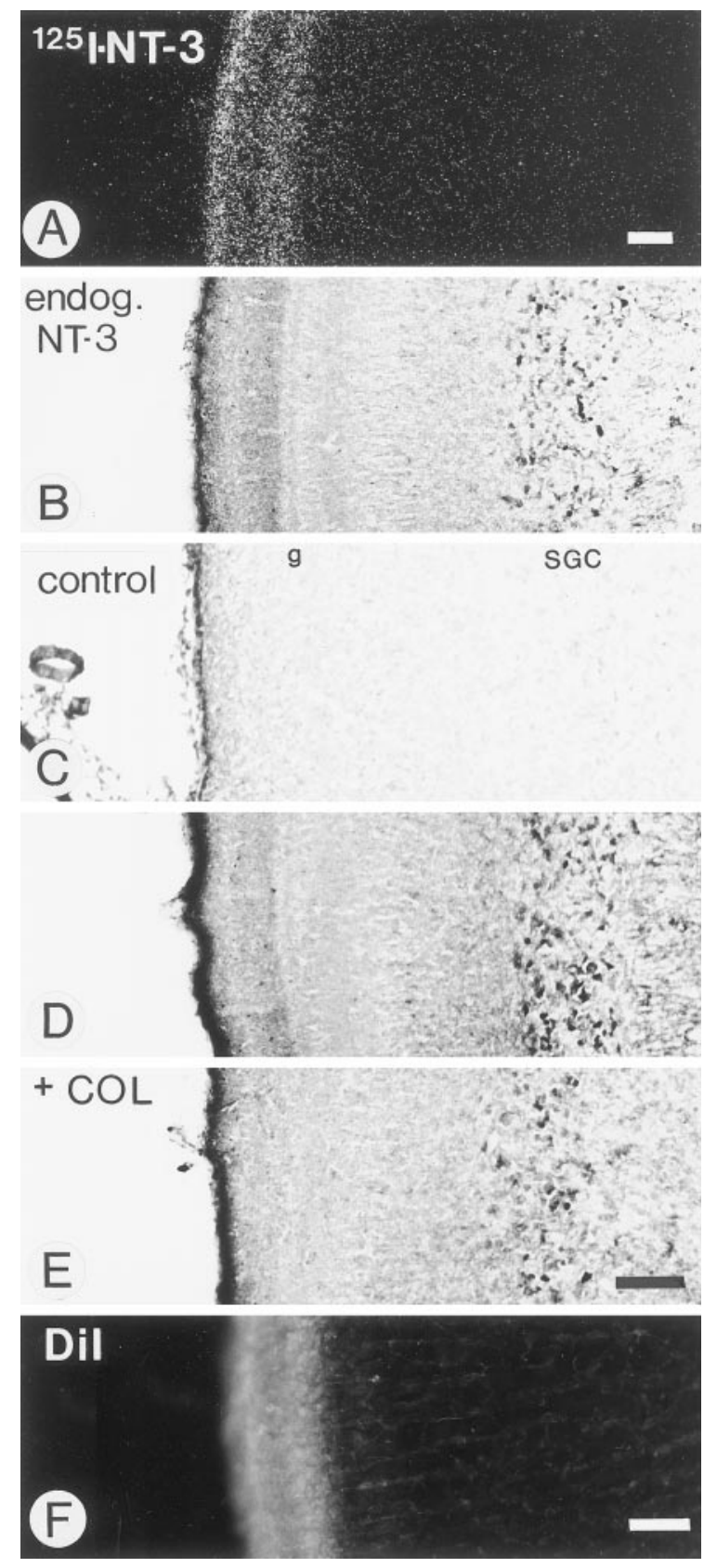

Figure 2. Sections through the superficial layers of the optic tectum of 16-d-old chick embryos showing the distribution of exogenous and endogenous (endog.) NT-3. A, Distribution of radiolabeled NT-3 in the optic tectum after injection in the eye and anterograde transport by retinal ganglion cell axons is shown. Dark-field image of a paraffin section processed for autoradiography. $B$, Normal tissue section immunolabeled with pAB to NT-3 shows a strong band of neuropil label in the same layers, the SO, and the SGFSa-d as well as cellular label in the SGC. Free-floating cryosection. The same pattern was seen with mAB to NT-3 (shown in $D$ ). $C$, No label was seen in control sections in which the primary antibody was replaced by irrelevant IgG. Free-floating cryosection. The layers SGFSg $(g)$ and SGC are indicated. $D$, Section through the ipsilateral (control) optic tectum $48 \mathrm{hr}$ after the intraocular injection of colchicine and immunolabeled with mAB to NT-3 is shown. Free-floating section. Note a normal band of NT-3 immunoreactivity. $E$, Same section shown in $D$ but from the contralateral optic tectum. Note that intraocular colchicine $(C O L)$ largely reduced the NT-3 label in the SO and SGFSa-d, demonstrating that NT-3-like immunoreactivity was derived from the retina and was present in retinotectal axons. $F$, Fluorescent label in the SO and SGFSa-d layers of the contralateral tectum after injection of DiI into the eye is shown. Cryosection. Scale bars: $A, B-E, F, 100 \mu \mathrm{m}$.
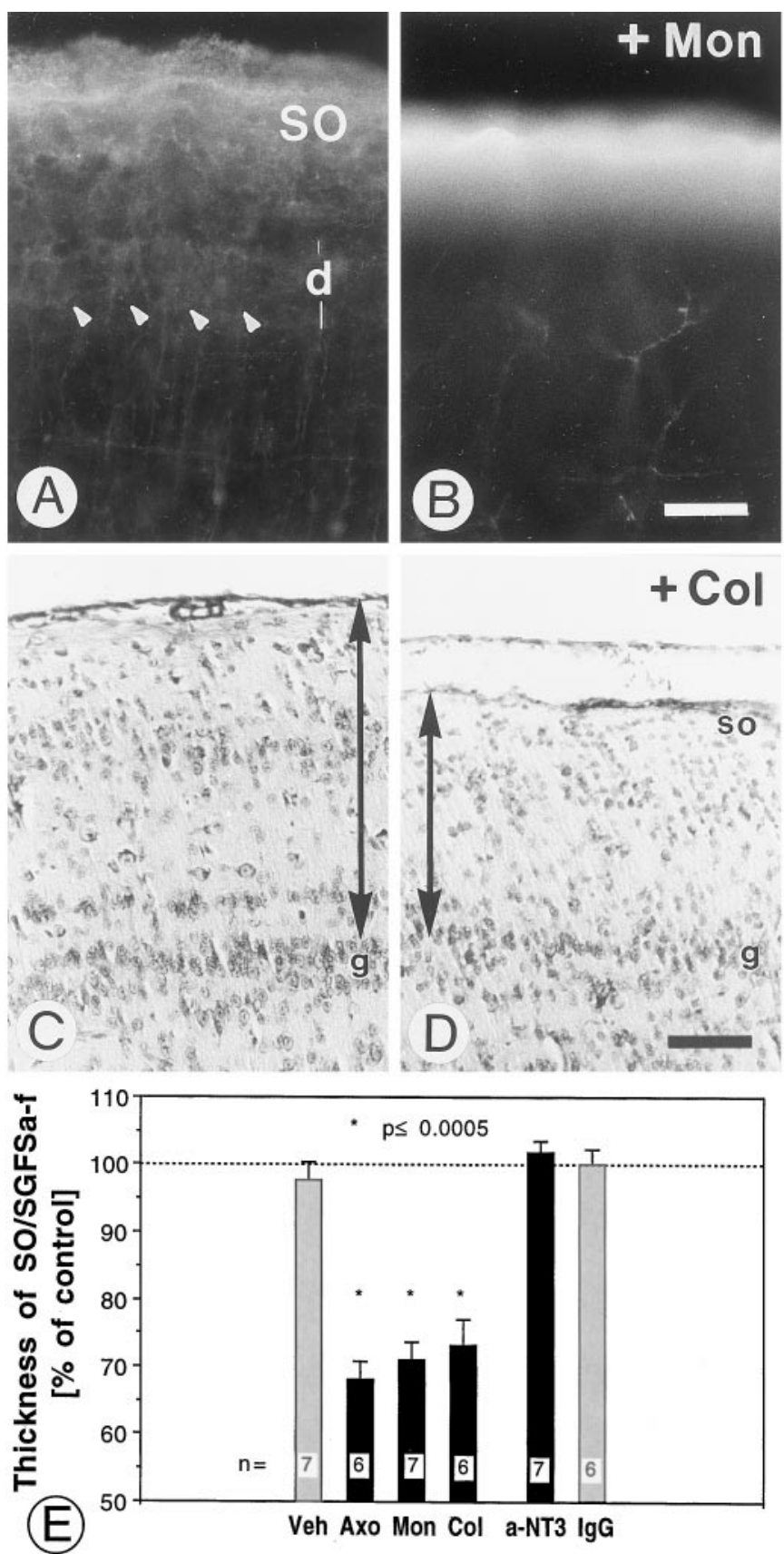

Figure 3. Effects of intraocular monensin, colchicine, and NT-3 antibodies on retinotectal projections in chick embryos. $A$, DiI application to the fixed retinotectal projection shows DiI label in the SO and SGFSd $(d$, arrowheads). B, Pretreatment with monensin $(+$ Mon $)$ in the eye abolishes DiI label in SGFSd and results in diffuse DiI label in the SO. $C$, The thickness (arrow) of the SO and SGFSa-f in the normal tectum [layer SGFSg is indicated $(g)$ ] is shown. $D$, Pretreatment of the eye with colchicine $(+\mathrm{Col})$ reduces the thickness (arrow) of the SO and SGFSa-f. $E$, Quantification of changes in the thickness of the SO + SGFSa-f tectal layers (ipsilateral vehicle control side $=100 \%$ ) is shown. Note that axotomy, monensin, and colchicine cause a similar reduction in the thickness of the retinorecipient tectal layers, at least in part because of degeneration of retinotectal fibers and terminals. Error bars indicate SEM. The number of independent experiments $(n)$ is indicated. $a-N T 3$, NT-3 antibody; Axo, axotomy; $\operatorname{Ig} G$, normal IgG control; Veh, vehicle. Scale bars: $A, B ; C, D, 50 \mu \mathrm{m}$. 


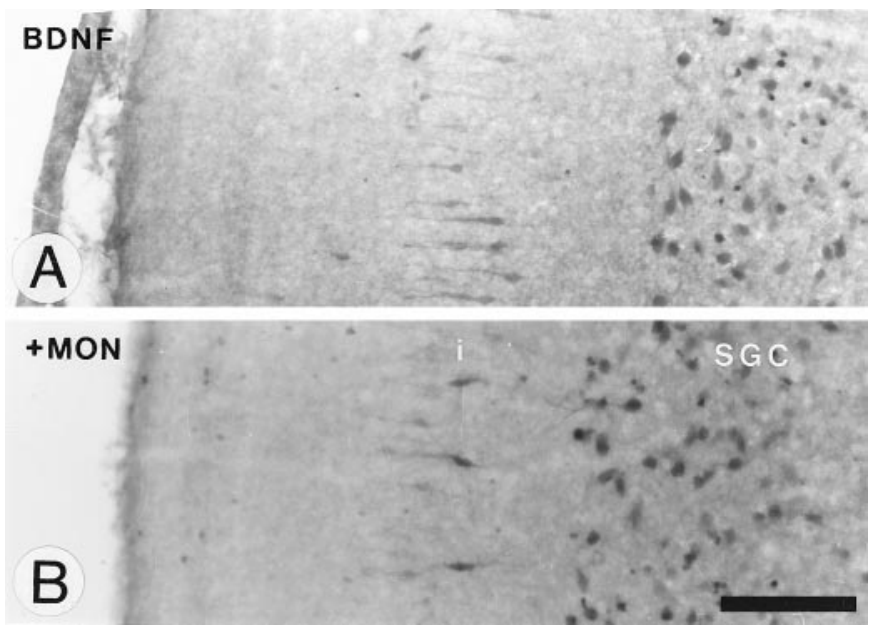

Figure 4. Sections through the optic tectum of a 16-d-old chick embryo immunolabeled for BDNF. $A$, Section through the ipsilateral (control) tectum. $B$, Section through the experimental tectum, contralateral to the eye that was injected with monensin $(M O N)$ to block anterograde transport and induce RGC axon degeneration in the tectum. Layer SGFSi $(i)$ is indicated. Note that there is no appreciable difference in BDNF label between the two sides of the same tissue section. Scale bar, $100 \mu \mathrm{m}$.

\section{Lack of transport of endogenous BDNF}

Endogenous BDNF has been shown to be transported anterogradely in several neuronal populations (Zhou and Rush, 1996; Altar et al., 1997; Conner et al., 1997; Smith et al., 1997; Yan et al., 1997), and it has been suggested that it may be transported in the retinotectal projection (Garner et al., 1996). A small fraction of chick RGCs produce BDNF (Herzog and von Bartheld, 1998; Karlsson and Hallböök, 1998). To determine whether endogenous BDNF is also transported by RGCs to the tectum, colchicine or monensin was injected in the eye, and sections through the tectum were immunolabeled with an antibody specific for BDNF (Jungbluth et al., 1994; Herzog and von Bartheld, 1998). There was no apparent difference in the pattern of immunolabeling for $\mathrm{BDNF}$ in the retinorecipient layers of the optic tectum, although cell bodies and dendrites were labeled in the deeper tectal layers (Fig. 4). Thus, there was no evidence that endogenous BDNF was transported by RGCs to the tectum, but we cannot exclude that such transport may be detected with more sensitive antibodies. Nevertheless, these data eliminate the possibility that loss of NT-3 label in the retinorecipient layers may be a nonspecific artifact of toxin treatment that is seen with all antibodies. Rather, the anterograde transport of endogenous neurotrophin by RGCs appears to be specific for NT-3.

\section{Is NT-3 expressed in RGCs and/or the optic tectum?}

In situ hybridization for $N T-3 \mathrm{mRNA}$

NT-3 protein has been detected in many neurons of the GCL in retinal sections from E15 to E17 chick embryos by immunocytochemistry with polyclonal and monoclonal antibodies specific for NT-3 (see Figs. 1C, 6A) (Das et al., 1997). To determine whether cells in the GCL (presumptive RGCs) express NT-3 mRNA themselves (von Bartheld et al., 1996a) or whether RGCs take up NT-3 from other cells in the retina that express NT-3 mRNA (Hallböök et al., 1996), we performed in situ hybridization experiments. Low levels of NT-3 mRNA were detected in the GCL at E15-E16 (von Bartheld et al., 1996a), and low levels of NT-3 mRNA were present in some cells of the GCL (Fig. 5A,B). However, because approximately one-third of the cells in the
GCL are amacrine cells (Ehrlich, 1981), it was not certain that NT-3 mRNA expression in the GCL was localized to the RGC population. Attempts to label RGCs retrogradely and detect NT-3 hybridization signals failed (data not shown), presumably because of the low copy number of neurotrophin mRNA in the chick retina (estimated to be $\sim 1.2$ copies/cell) (Herzog et al., 1994; Hallböök et al., 1996). Similar experiments detected BDNF signal that is expressed at higher levels in a small subpopulation of RGCs (Herzog and von Bartheld, 1998; Karlsson and Hallböök, 1998).

\section{RT-PCR of purified RGCs and random tectal cells}

To resolve whether RGCs in the ganglion cell layer (Fig. 6A) express the gene for NT-3, we used RT-PCR from $100 \%$ purified RGCs. Expression of NT-3 mRNA and 18 S rRNA was consistently detected in 600-1000 random retinal cells as well as in 600-1000 purified RGCs from E19 to E20 chicken embryos (Fig. $6 B)$. High-abundance $18 \mathrm{~S}$ rRNA was detected after one round of PCR, whereas expression of the low-abundance NT-3 gene was consistently detected after a second round of PCR by using nested primers. Our protocol (Butowt et al., 2000) purified RGCs to $100 \%$ purity. Analysis of sectioned retinae after injections of DiI into the optic nerve verified that only cells in the GCL and large displaced ganglion cells in the INL were labeled, but no other cell types (Butowt et al., 2000). Whether the large displaced ganglion cells project to the optic tectum in chicken is controversial (Reiner et al., 1979), and therefore we had to consider the possibility that the observed NT-3 signal may be caused entirely by expression in this cell type. However, neither the in situ hybridization nor the immunolabeling data provided any indication that the displaced ganglion cell type may express larger quantities of NT-3 than do orthotopic RGCs (data not shown).

By the use of RT-PCR with the same conditions used for retinal cells, NT-3 expression could not be detected in four independent PCR experiments with RNA extracted from 1000 to 2000 cells derived from the superficial layers of the optic tectum from the same embryos (Fig. 6B). These data confirm the reported lack of NT-3 expression in this region (von Bartheld et al., 1996a; Karlsson and Hallböök, 1998). No signal was detected in experiments without reverse transcriptase or with water instead of RNA. We conclude that RGCs express NT-3, although at low levels.

\section{Prevention of NT-3 release in the retina with pertussis toxin}

The RT-PCR experiments showed that RGCs express at least some NT-3 themselves, but these experiments do not exclude that a major fraction of the anterogradely transported NT-3 may be taken up from other retinal cells. If much of the retinal NT-3 was produced by INL and outer nuclear layer (ONL) cells (Hallböök et al., 1996) and then transferred to RGCs, one would predict a loss or reduction of NT-3 label in the GCL when immunolabeled for NT-3 after blockade of intraretinal release or transfer of NT-3. Pertussis toxin (PTX) was injected in the eye that is known to reduce the secretion of neurotrophins (Gunther et al., 1996). To verify the success of the PTX injections in the eye, pyknotic profiles in samples of the SGC layer of the ipsilateral and contralateral optic tectum were quantified. This analysis showed a nearly $100 \%$ increase in the number of dying cells in the contralateral SGC. Yet, there was no substantial decrease in the NT-3 immunolabel of the GCL, visualized with either the mAB or the pAB (Fig. 5C,D). PTX induced a more homogeneous distribution of NT-3 label in the INL, suggesting that normal movement of NT-3 protein from the outer half of the INL to the 


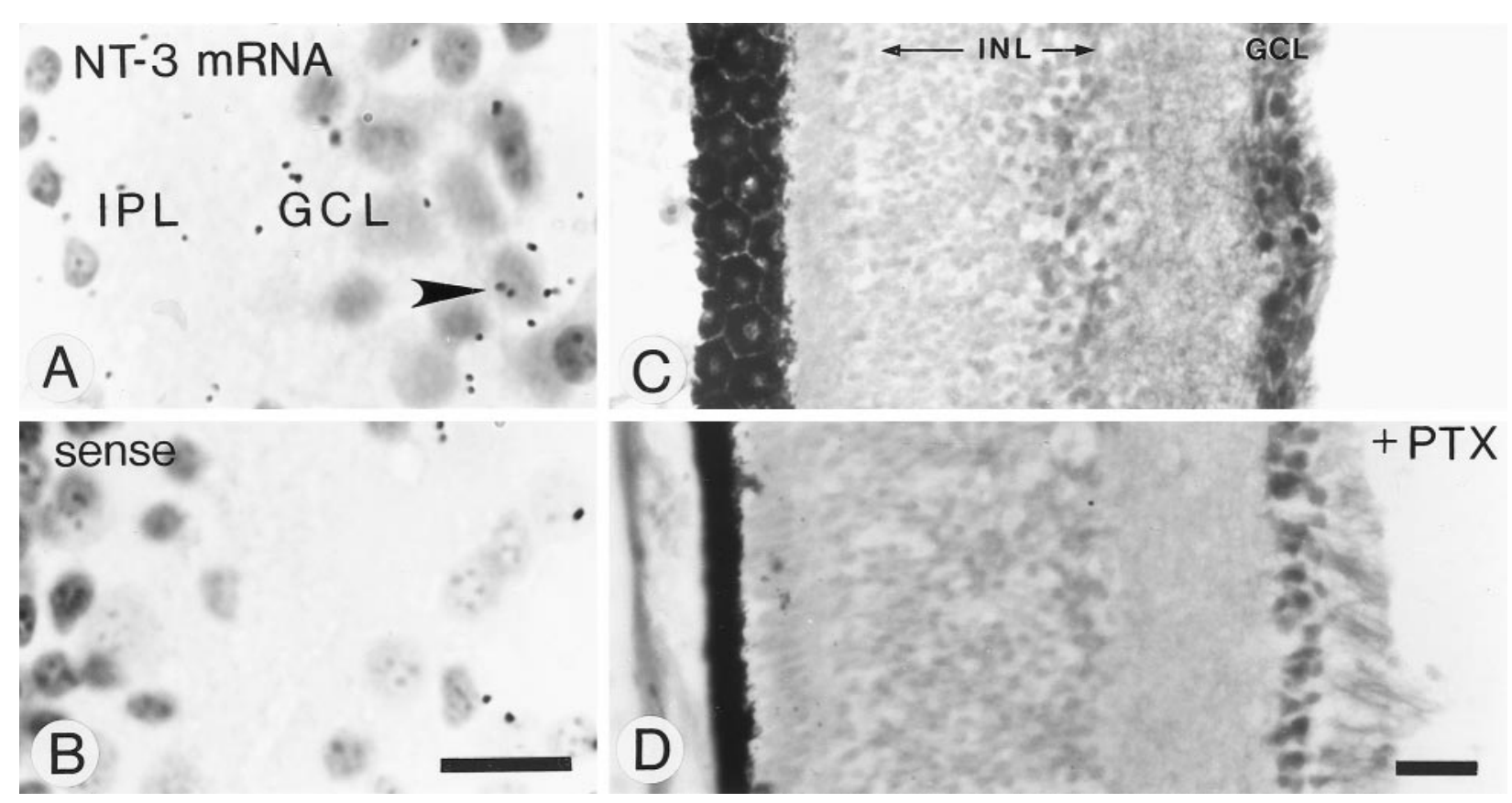

Figure 5. Sections through the retina of a 16-d-old chick embryo hybridized with a probe for NT-3 $(A, B)$ or immunolabeled for NT-3 protein $(C, D)$. $A$, Section hybridized with the antisense probe for NT-3. Note the label in some cells (arrowhead) within the GCL. $B$, Adjacent section hybridized with a sense control probe. $C$, Immunolabeled section through the normal (control) retina. Note that the INL is labeled differentially; the inner half is labeled more intensely than the outer half. $D$, Section through the retina of the same embryo in which pertussis toxin $(P T X)$ was injected into the eye. Note that $P T X$ changed the pattern of NT-3 distribution that became homogeneous throughout the INL, but PTX treatment did not consistently change the intensity or distribution of NT-3 label in the GCL. Scale bars: $A, B, 10 \mu \mathrm{m} ; C, D, 20 \mu \mathrm{m}$.

inner half was reduced by the PTX treatment. These data are consistent with the notion that a significant amount of NT-3 is produced by RGCs themselves.

\section{Blockade of intraretinal transfer of NT-3}

To determine further the extent to which RGCs may take up NT-3 from other retinal cells for anterograde transport, we determined the dose of blocking NT-3 antibody that is sufficient to abolish the transport of exogenous NT-3 from the retina to the tectum. This antibody reduced the transport of radio-iodinated NT-3 to the tectum in a dose-dependent manner (Fig. 7A). A dose of $2 \mu \mathrm{g}$ in the eye blocked $>90 \%$ of the transport that normally would have occurred, whereas even 10 -fold higher doses of irrelevant $\mathrm{IgG}$ did not significantly reduce the transport (Fig. $7 A$ ). We then injected $20 \mu \mathrm{g}$ of blocking NT-3 antibody in one eye of 15- to 17-d-old chick embryos and examined the optic tectum for NT-3 immunolabel. If a substantial amount of anterogradely transported NT-3 was not expressed by RGCs themselves but taken up from other cells in the retina, the blocking antibody would prevent the transfer of NT-3 within the retina, and there should be a reduction of the NT-3 immunolabel in the tectum. However, even daily injections of the $20 \mu \mathrm{g}$ dose of the blocking antibody in the eye did not reduce the intensity or the pattern of NT-3 immunoreactivity in the retinorecipient tectal layers (Fig. $7 B, C)$. Thus, we conclude that the RGCs produce at least a major fraction of the anterogradely transported NT-3 themselves.

Unexpectedly, the cellular pattern of NT-3 immunolabel in the optic tectum was altered with injections of the blocking NT-3 antibody in the eye. In the tectum innervated by the controlinjected eye, NT-3 immunolabel in cell bodies was restricted to the SGC layer (Fig. $7 B$ ), but in the tectum receiving innervation from the retina injected with the NT-3-blocking antibody, many cells in the SGFS layer were immunolabeled for NT-3 (Fig. 7C). This effect was not seen in tecta when the eye was injected with control antibodies. It remains to be determined whether this may represent de novo expression of NT-3 by the SGFS cells or whether NT-3 protein becomes distributed differently in SGFS neurons as a result of interference with NT-3 signaling in the eye or in the tectum. To determine whether the NT-3 mAB may be transported from the eye to the tectum and may accumulate in tectal neurons, the NT-3 mAB was radiolabeled and injected in the eye. There was no evidence of transport to, and accumulation in, the tectum by either gamma counting or emulsion autoradiography of sections through the tectum (data not shown), but we cannot exclude the possibility that radio-iodination of the antibody may have altered its function.

As a final approach to the question of the source of anterogradely transported NT-3, cell death in the optic tectum was analyzed after injection of blocking NT-3 antibody or control antibody in the eye. There was no significant increase in cell death in the SGC $48 \mathrm{hr}$ after a single injection of 2 or $22 \mu \mathrm{g}$ of blocking $\mathrm{mAB}$ in the retina when compared with control injections (Fig. $7 D, E)$. However, daily injections of $22 \mu \mathrm{g}$ of $\mathrm{mAB}$ over 3-4 d induced a significant enhancement of cell death in the SGC compared with control injections, and this was apparently not caused by retinotectal fiber degeneration, because the thickness of the SO and SGFSa-f layers was not reduced (Fig. $3 E$ ), and daily injections of the NT-3 mAB did not increase the frequency of pyknotic cells in the GCL (data not shown). These data indicate that much of the anterogradely transported NT-3 is produced by RGCs, but this amount needs supplementation from other retinal sources, because prolonged lack of supply from 


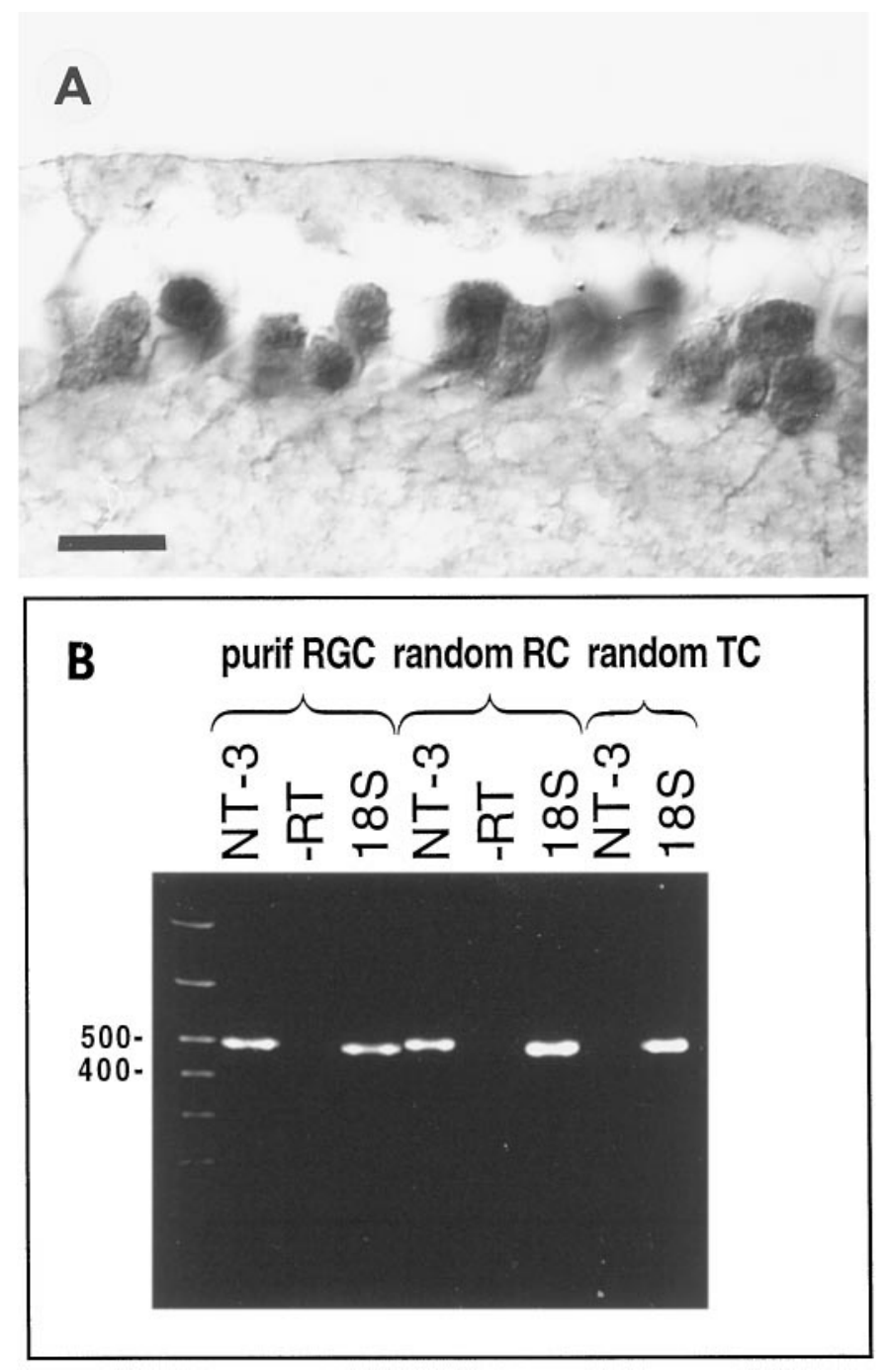

Figure 6. NT-3 expression in RGCs. $A$, NT-3-like immunoreactivity in the ganglion cell layer of a 16-d-old chick embryo. The cryosection is immunolabeled with the monoclonal NT-3 antibody. Scale bar, $10 \mu \mathrm{m} . B$, RT-PCR analysis for NT-3 expression in 1000 purified (purif) RGCs, 1000 random retinal cells $(R C)$, and 2000 random tectal cells $(T C)$. The number of base pairs $(400,500)$ is indicated. The NT-3 product is $498 \mathrm{bp}$; the $18 \mathrm{~S}$ rRNA product is $488 \mathrm{bp}$. Note that the NT-3 signal is obtained from purified RGCs and random retinal cells but not from random tectal cells. $-R T$, Minus reverse transcriptase; $18 S, 18 \mathrm{~S}$ ribosomal RNA.

additional retinal sources of NT-3 appears to be fatal for many SGC neurons.

\section{Localization of neurotrophin receptors in the retinotectal projection}

Previous studies have indicated that the bulk of the anterograde transport of exogenous NT-3 is receptor-mediated (von Bartheld et al., 1996a). Cells in the chicken GCL express mRNAs for the neurotrophin receptors p75, trkB, and trkC (von Bartheld et al., 1991; Hallböök et al., 1996). To determine which neurotrophin receptors may be present within retinotectal terminals, immunocytochemistry with antibodies to $\mathrm{p} 75, \operatorname{trkB}, \operatorname{trkC}$, and truncated trkC was performed. The trkB antibody labeled cell bodies in the SGFSc and g and SGC layers of the optic tectum (Fig. 8A). The trkC antibody labeled many cells throughout the SGFS and SGC (Fig. $8 B$ ). The antibody against truncated trkC labeled cell bodies in the SGC (data not shown). Neither of the trk antibodies labeled a distinct band of neuropil in the retinorecipient tectal layers. Immunocytochemistry with a monoclonal antibody specific for chicken p75 (Tanaka et al., 1989; von Bartheld et al., 1995) showed that strong p75 immunoreactivity was present in the neuropil-containing retinotectal fibers and terminals (tectal layers SO and SGFSa-d, Fig. 8D). Label was heaviest in SGFSd, moderate in SO and SGFSa and b, and weaker in SGFSc. Thus, the p75 antibody labeled those tectal layers with abundant retinotectal terminals (Crossland et al., 1975; Acheson et al., 1984) that also contain NT-3-like immunoreactivity (Fig. 2B). Control sections showed no label when the primary antibody was omitted (Fig. 8C). These data indicate that p75 receptors may be transported by RGCs to their axon terminals.

\section{Source and transport of p75 receptors in the retinotectal projection}

Several neuronal cell types in the SGFS layer of the optic tectum express p75 mRNA (von Bartheld et al., 1991) and contain p75 protein (present study). Therefore, it was not clear whether the p75 label in the retinorecipient layers was contained within processes from intrinsic tectal neurons or was caused by anterograde transport of p75 within RGC projections. To determine whether RGCs transport p75 protein to their axon terminals, we injected monensin or colchicine in one eye of E16 chick embryos and examined the optic tectum for p75 immunolabel. When transport from the retina was abolished and terminal degeneration of retinotectal fibers likely was in progress, there was a marked decrease of the p75 neuropil label in the SGFSc and d layers of the contralateral optic tectum (Fig. 8D,E). The p75 immunolabel of the neuronal cell bodies and their primary and secondary dendrites in the SO and SGFSa and b was not affected, thus serving as an internal positive control. These results demonstrate that a substantial amount of the p75 protein in the SGFSc and $\mathrm{d}$ was derived by anterograde transport from the RGCs.

We have shown previously that exogenous BDNF, when injected into the optic tectum, is transported retrogradely by retinotectal axons to the retina, presumably by binding to p75 receptors (Herzog and von Bartheld, 1998). To determine whether exogenous NT-3 is also transported retrogradely in this system, we injected ${ }^{125}$ I-NT-3 into the tectum of 20 - to 21 -d-old chick embryos. Successful injections showed that $\sim 0.5-1.2 \mathrm{ng}$ of ${ }^{125} \mathrm{I}-$ NT-3 remained in the tectum at the time of death, as measured by gamma counting of the dissected tecta. There was no difference in the amounts of radioactivity between the experimental eyes and the control eyes, but differences could have been obscured by systemic leakage. When the retinae were dissected from the eye, dehydrated, and then measured in a gamma counter, there was a slight difference (increase) of $\sim 30 \mathrm{cpm}(0.2 \mathrm{pg})$ between the contralateral (experimental) and the ipsilateral (control) retinae, indicating that as much as $0.2 \mathrm{pg}$ of ${ }^{125} \mathrm{I}-\mathrm{NT}-3$ (equivalent to $0.02 \%$ of the amount that remained in the tectum) may have been transported retrogradely to the contralateral retina. The efficiency of this retrograde transport is 20 times less than that of anterograde transport after injection in the eye, but it has to be kept in mind that differences between retinotectal and tectoretinal transport could also be caused by technical difficulties such as differences in applying and retaining access of the exogenous neurotrophin for internalization at the injection site.

Taken together, our data are consistent with the notion that the p75 receptor is a major carrier of exogenous, and possibly endogenous, NT-3 in the retinotectal pathway (von Bartheld, 1996) and 

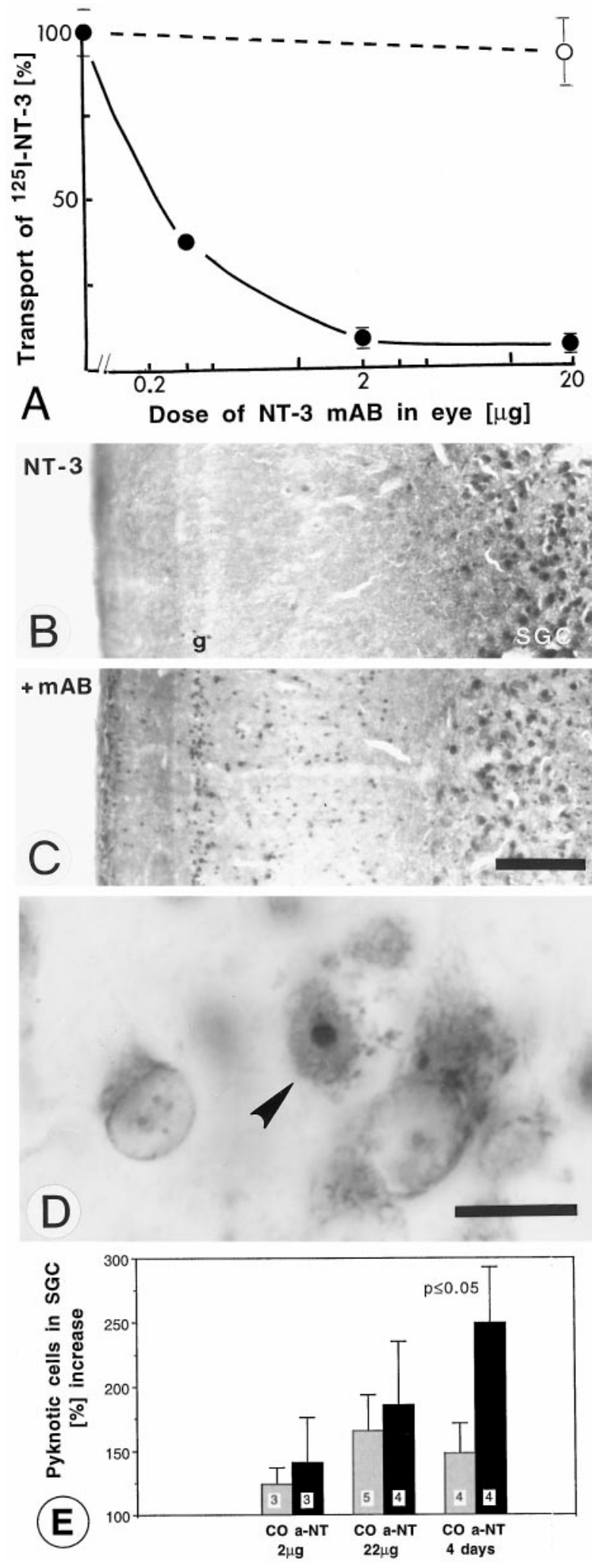

Figure 7. Effects of the blocking NT-3 mAB in the eye on the distribution of NT-3 and cell death in the tectum. $A$, Dose-response curve of the effect of blocking $\mathrm{mAB}$ to NT-3 in the eye on the transport of radioiodinated NT-3 from the eye to the midbrain in 15- to 16-d-old chick embryos. mAB $(0.4 \mu \mathrm{g})$ blocks $\sim 60 \%$ of the transport, $2 \mu \mathrm{g}$ blocks $\sim 90 \%$, and $20 \mu \mathrm{g}$ blocks $\sim 95 \%$. Each data point with error bars (SEM) is the average of three to eight experiments. Dashed line, Control antibody. $B, C$, Sections through the optic tectum of a 16-d-old chick embryo a carrier of BDNF in the retrograde direction (Curtis et al., 1995; Herzog and von Bartheld, 1998). The distribution of NT-3, p75, trkB, and trkC protein in the superficial tectal layers and their sources are schematically summarized in Figure 9.

\section{DISCUSSION}

Recent studies have shown that neurotrophins are not only retrograde trophic molecules but that they may have important functions as messengers that are transported in the anterograde direction along axons. Anterograde transport of at least some neurotrophins is now thought to be the predominant form of transport in the adult CNS (Conner et al., 1997). NGF can be transported anterogradely in some pathways (Wayne and Heaton, 1990; Hoyle et al., 1993), but not in others (Claude et al., 1982; Ferguson et al., 1990). Recent studies with BDNF and NT-3 have demonstrated the anterograde transport of exogenous NT-3 (von Bartheld et al., 1996a; Johnson et al., 1997) and of exogenous and endogenous BDNF (Zhou and Rush, 1996; Altar et al., 1997; Conner et al., 1997; Johnson et al., 1997; Smith et al., 1997; Yan et al., 1997). In agreement with the notion of anterograde transport of neurotrophins, BDNF has been shown to accumulate in axon terminals (Fawcett et al., 1997; Michael et al., 1997), and functional trk receptors have been localized to the postsynaptic density (Levine et al., 1995; Wu et al., 1996). Anterograde transport is technically difficult to demonstrate because the amounts transported to the terminals can be two to three orders of magnitude lower than those that are transported retrogradely to the cell bodies (von Bartheld et al., 1996a,b). For this reason, the axonal transport of neurotrophins in the retinotectal projection of chick embryos is of considerable interest. In this system, 3-4 $\times$ $10^{6}$ RGCs project onto a relatively thin layer of the contralateral optic tectum (Rager, 1980). The strong convergence, lack of direct tectoretinal projections (i.e., the lack of potential retrograde axonal transport), and the lack of production of NT-3 in the target, the optic tectum (von Bartheld et al., 1996a; Karlsson and Hallböök, 1998), make this an ideal system for the study of anterograde axonal transport of NT-3 (LaVail and Margolis, 1987; von Bartheld, 1998a).

\section{Evidence of the anterograde transport of endogenous NT-3}

Anterograde transport of endogenous trophic factors has been demonstrated previously for insulin-like growth factor-I (Hansson et al., 1987), BDNF (for review, see Conner et al., 1998), and possibly glial cell line-derived neurotrophic factor (Holstege et al., 1998). Our paper presents the first direct evidence of the anterograde transport of endogenous NT-3. The validity of this

immunolabeled for NT-3 after daily injections of $20 \mu \mathrm{g}$ of NT-3 mAB in one eye. Note the persistence of NT-3 label in the retinorecipient neuropil of layers SGFSa-d in the antibody-treated retinotectal projection $(C)$ compared with the ipsilateral control side $(B)$. The experimental tectum showed an increase in the number of NT-3-labeled cell bodies in SGFSg-i. D, Example of a pyknotic cell (arrowhead) in the SGC of a 16-d-old chick embryo. E, Quantification of pyknotic neuronal profiles in the optic tectum after injections of 2,22 , or $3 \times 22 \mu \mathrm{g}$ of NT-3 mAB $(a-N T)$ in the eye or of irrelevant, control antibody $(C O)$ in the eye. Bar graphs show a significant effect ( $p \leq 0.05, t$ test) of NT-3 mAB in the eye on the cell death of neurons in the SGC of the contralateral optic tectum only after multiple high doses over $4 \mathrm{~d}$. The number of independent experiments is indicated on each vertical bar. Error bars indicate SEM. These data are consistent with the hypothesis that RGCs export primarily their own NT-3 to the optic tectum so that depletion of extrinsic sources becomes relevant only after $3-4 \mathrm{~d}$. Scale bars: $B, C, 100 \mu \mathrm{m} ; D, 10 \mu \mathrm{m}$. 


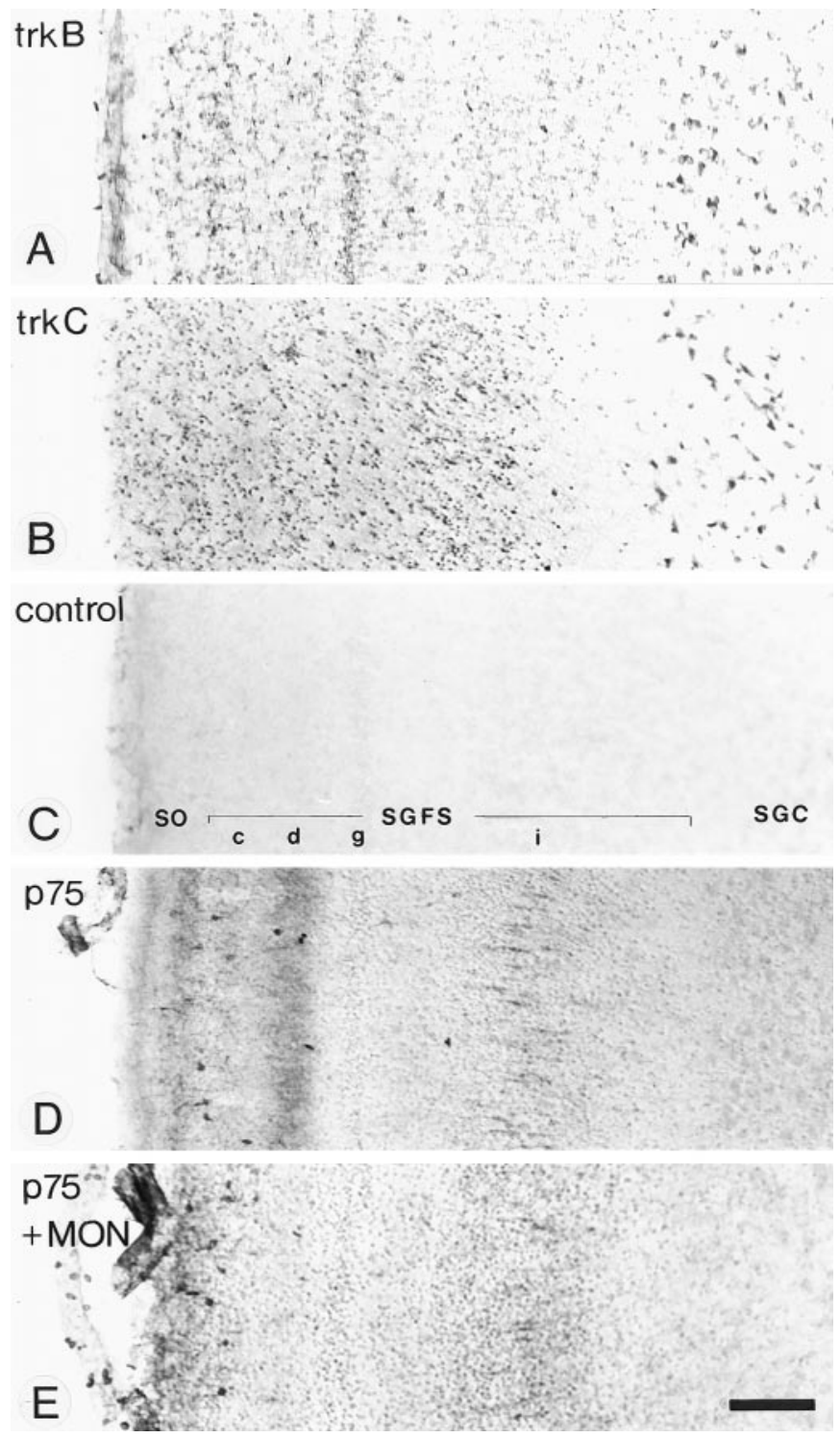

Figure 8. Sections through the optic tectum immunolabeled with antibodies to neurotrophin receptors. $A, B$, Sections labeled with $\mathrm{pAB}$ to trkB $(A)$ and $\mathrm{pAB}$ to trkC $(B)$. Note the lack of neuropil label within the retinorecipient layer SGFSd. $C$, Control section in which the primary antibody was omitted. The layers of the optic tectum are indicated. $D$, Section labeled with a mAB to the p75 neurotrophin receptor. p75 label distributes in the same sublayers of the SO and SGFSa-d as the exogenous and endogenous NT-3 (compare with Fig. $2 A, B$ ). $E$, Section through the experimental (contralateral) optic tectum of the same tissue section after injection of monensin in the eye. Note the absence of p75 immunoreactivity in the SGFSd but the normal appearance of p75-labeled neuronal cell bodies in SGFSc and SGFSi. Scale bar, $100 \mu \mathrm{m}$.

interpretation is based on the use of two different antibodies that are both specific and sensitive, and they rendered virtually identical results. Furthermore, different ways of blocking anterograde transport were used; monensin is specific for blockade of anterograde transport (Hammerschlag and Stone, 1982; Hammerschlag et al., 1982), whereas colchicine blocks both the retrograde and the anterograde transport. Both toxins also induce RGC death and retinal axon degeneration. Our data show that RGCs transport endogenous NT-3 to their terminals in the optic tectum. Thus, the anterograde transport of radio-iodinated, exogenous, NT-3 in this pathway (von Bartheld et al., 1996a) reflects a

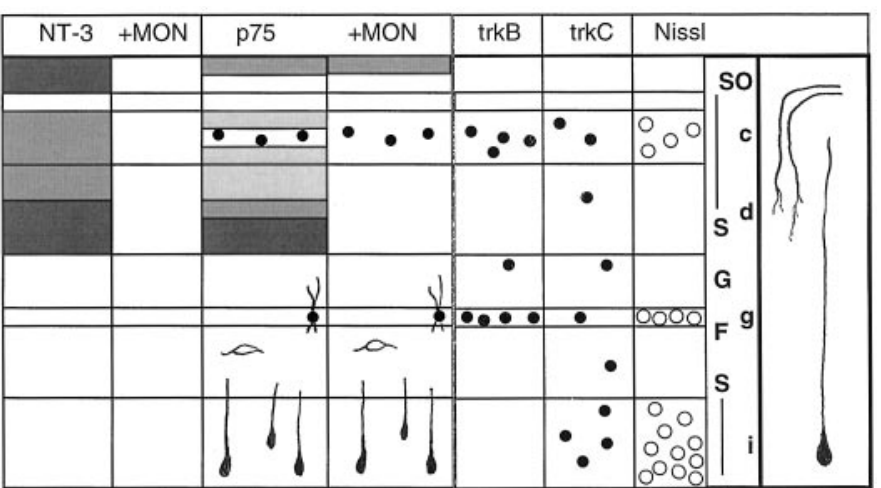

Figure 9. Synopsis of NT-3 immunolabel and neurotrophin receptor immunolabel in the superficial layers of the optic tectum in 16-d-old chick embryos and their sources from within the tectum or retinal projection. Shaded (gray) areas indicate neuropil label, graded from light (low levels) to dark (high levels). Labeled cell bodies are indicated by dots or profiles (when dendritic details are labeled). + MON, Monensin added in the eye (to reveal nonretinal source of label; intraocular monensin prevents anterograde axonal transport and causes degeneration of RGC axons and axon terminals). The right-hand panel depicts the fiber course of retinal ganglion cell axons in the SO and the SGFS and the morphology of tectal neurons in sublayer SGFSi with ascending dendrites into SGFSg, d, and c.

process that occurs normally in this animal. The apparent lack of anterograde transport of BDNF in the retinotectal projection suggests specificity of this process among the neurotrophins. Anterograde transport of NT-3 may be a common feature in laminated structures. Granule cells of the cerebellum may produce NT-3 for cerebellar Purkinje cells and transfer the NT-3 after anterograde transport (Lindholm et al., 1993). Endogenous BDNF and NT-3 have effects on the dendritic growth of pyramidal neurons in cortex slices (McAllister et al., 1999), possibly mimicking a physiological function of anterogradely transported neurotrophins in vivo.

\section{The source of NT-3 in the retina}

We have demonstrated previously that RGCs transport exogenous NT-3 from the retina to the optic tectum, and we have shown axodendritic transfer of NT-3 (von Bartheld et al., 1996a). The anterograde transport of the exogenous neurotrophin suggested that RGCs may similarly transport endogenous NT-3. We now have shown that this is the case. The source of the endogenous NT-3 in the retinotectal system was controversial. Hallböök et al. (1996) reported NT-3 mRNA expression only in the ONL and the outer half of the INL of the retina, but not in the GCL. This localization would indicate that RGCs take up NT-3 produced by other cells in the retina, presumably bipolar or Müller cells, whereas the study by von Bartheld et al. (1996a) indicated that low levels of NT-3 may be expressed in the GCL.

Our study shows that RGCs, rapidly purified to $100 \%$, express NT-3 mRNA and that RGCs efficiently transport endogenous NT-3 anterogradely to the optic tectum. In addition, we conclude that a major fraction of the anterogradely transported NT-3 is produced by the RGCs themselves rather than taken up by RGCs from other cells in the retina. Intraocular injections of pertussis toxin, which reduces the release of neurotrophins (Gunther et al., 1996), did not decrease NT-3 label in the GCL, and functionblocking NT-3 antibody that reduces the uptake (and thus the anterograde transport) of exogenous NT-3 by RGCs did not reduce the transport of endogenous NT-3 to the superficial layers of the optic tectum. Such a reduction of NT-3 transport was 
readily achieved with either monensin or colchicine. These substances block the anterograde transport of NT-3, regardless whether it is produced by RGCs or taken up from other cells. The loss of NT-3 protein in the superficial layer of the optic tectum may be caused by the elimination of anterograde transport as well as degeneration of retinal axons as a result of the exposure of RGCs to the toxin.

\section{The role of p75 in neurotrophin transport}

The "low-affinity" p75 neurotrophin receptor has been implicated in the retrograde axonal transport of neurotrophins. For NGF, the role of p75 is controversial (Taniuchi and Johnson, 1985; Johnson et al., 1987; Kiss et al., 1993; Bothwell, 1995; Curtis et al., 1995), but not for BDNF, NT-3, and NT-4 (Curtis et al., 1995; Ibáñez, 1996; von Bartheld et al., 1996b). Recent data on crosslinking and immunoprecipitation of neurotrophins during anterograde axonal transport (von Bartheld, 1996) have implicated p75 as a major carrier of exogenous NT-3. In agreement with these data, cells in the GCL express p75 receptor mRNA heavily (von Bartheld et al., 1991), and p75 expression by RGCs can be concluded because our study shows that $\mathrm{p} 75$ protein is present in the retinotectal projection. Different p75 antibodies show different intensities of immunolabel in the RGC cell bodies (Das et al., 1997; Herzog and von Bartheld, 1998), but p75 protein is clearly present in the retinotectal projection (present study). Differential retrograde and anterograde axonal transport of neurotrophins and/or differential cell-death/survival signaling may be regulated by p75 targeting (Carter and Lewin, 1997). If the p75 receptor acts as a "shuttle" of neurotrophins between the cell body and the axon terminal, it is possible that p75 delivers NT-3 from the cell body to the axon terminals on the anterograde route and takes BDNF back from the terminals to the cell body on the retrograde route (Herzog et al., 1994; Herzog and von Bartheld, 1998), possibly delivering a death signal (Frade et al., 1996). Thus, the multifunctional p75 receptor may be used as a neurotrophin carrier in both directions of axonal transport.

\section{Possible functional significance of anterograde neurotrophin transport}

The first functional studies on anterograde transport of neurotrophins have examined the survival and phenotype of target neurons (von Bartheld et al., 1996a; Altar et al., 1997), but it was difficult to demonstrate conclusively that effects were caused by the direct action of the anterogradely transported neurotrophic factor. Neurotrophins have many additional roles in the developing and mature nervous system (Snider, 1994). Some of these functions are on the efficacy and plasticity of synapses (Lohof et al., 1993; Kang and Schuman, 1995; Thoenen, 1995; Berninger and Poo, 1996; Snider and Lichtman, 1996); others are on formation and branching of neurites (Cohen-Cory and Fraser, 1995; McAllister et al., 1999). The demonstrated functions of neurotrophins on dendritic growth in laminated structures (McAllister et al., 1999) are of particular interest. Many cell types have distinct lamina-specific apical and basal dendritic geometries in the avian tectum in which 16 layers have been distinguished (LaVail and Cowan, 1971; Hunt and Brecha, 1984). The formation of such layer-specific domains may be regulated by neurotrophins. The work of McAllister and her colleagues has demonstrated that neurotrophins interact in their influences on dendritic growth in cortex slices and can have opposing effects that are specific for certain layers within the cortex. The release of NT-3 from axon terminals is increased by depolarization (Wang et al., 1999), and the expression of at least some neurotrophins is regulated by neuronal activity (Lindholm et al., 1994). Thus, neurotrophins, whether acting as retrograde or anterograde messengers, may have substantial influences on the activitydependent fine tuning of circuitry in the developing brain, and this is a current focus of our lab.

\section{REFERENCES}

Acheson DWK, Kemplay SK, Webster KE (1984) Quantitative analysis of optic terminal profile distribution within the pigeon optic tectum. Neuroscience 5:1067-1084.

Altar CA, DiStefano PS (1998) Neurotrophin trafficking by anterograde transport. Trends Neurosci 21:433-437.

Altar CA, Cai N, Bliven T, Juhasz M, Conner JM, Acheson AL, Lindsay RM, Wiegand SJ (1997) Anterograde transport of brain-derived neurotrophic factor and its role in the brain. Nature 389:856-860.

Anderson KD, Alderson RF, Altar CA, DiStefano PS, Corcoran TL, Lindsay RM, Wiegand SJ (1995) Differential distribution of exogenous BDNF, NGF, and NT-3 in the brain corresponds to the relative abundance and distribution of high-affinity and low-affinity neurotrophin receptors. J Comp Neurol 357:296-317.

Baeten JM, Bothwell M, Sudra AH, von Bartheld CS (1997) Quantification of anterogradely transported neurotrophin-3 and measurement of its release from retinal ganglion cell axon terminals in the developing chick optic tectum. J Investig Med 45:A109.

Barde Y-A (1989) Trophic factors and neuronal survival. Neuron 2:1525-1534.

Berninger B, Poo MM (1996) Fast actions of neurotrophic factors. Curr Opin Neurobiol 6:324-330.

Bothwell M (1995) Functional interactions of neurotrophins and neurotrophin receptors. Annu Rev Neurosci 18:223-253.

Butowt R, Jeffrey PL, von Bartheld CS (2000) Purification of chick retinal ganglion cells for molecular analysis: combining retrograde labeling and immunopanning yields $100 \%$ purity. J Neurosci Methods, in press.

Carter BD, Lewin GR (1997) Neurotrophins live or let die: does p75 NTR decide? Neuron 18:187-190.

Catsicas M, Péquignot Y, Clarke PGH (1992) Rapid onset of neuronal death induced by blockade of either axoplasmic transport or action potentials in afferent fibers during brain development. J Neurosci 12:4642-4650.

Chandler CE, Parsons LM, Hosang M, Shooter EM (1984) A monoclonal antibody modulates the interaction of nerve growth factor with PC12 cells. J Biol Chem 259:6882-6889.

Claude P, Hawrot E, Dunis DA, Campenot RB (1982) Binding, internalization, and retrograde transport of ${ }^{125} \mathrm{I}$-nerve growth factor in cultured rat sympathetic neurons. J Neurosci 2:431-442.

Cohen-Cory S, Fraser SE (1995) Effects of brain-derived neurotrophic factor on optic axon branching and remodeling in vivo. Nature 378:192-196.

Conner JM, Lauterborn JC, Yan Q, Gall CM, Varon S (1997) Distribution of brain-derived neurotrophic factor (BDNF) protein and mRNA in the normal adult rat brain: evidence for anterograde axonal transport. J Neurosci 17:2295-2313.

Conner JM, Lauterborn JC, Gall CM (1998) Anterograde transport of neurotrophin proteins in the CNS - a reassessment of the neurotrophic hypothesis. Rev Neurosci 9:91-103.

Crossland WJ, Cowan WM, Rogers LA (1975) Studies on the development of the chick optic tectum. IV. An autoradiographic study of the development of retinotectal connections. Brain Res 91:1-23.

Curtis R, Adryan KM, Stark JL, Park JS, Campton DL, Weskamp G, Huber LJ, Chao MV, Jaenisch R, Lee KF, Lindsay RM, DiStefano PS (1995) Differential role of the low-affinity neurotrophin receptor (p75) in retrograde axonal transport of the neurotrophins. Neuron 14:1201-1211.

Das I, Hempstead BL, MacLeish PR, Sparrow JR (1997) Immunohistochemical analysis of the neurotrophins BDNF and NT-3 and their receptors trkB, trkC, and $\mathrm{p} 75$ in the developing chick retina. Vis Neurosci 14:835-842.

Ehrlich D (1981) Regional specialization of the chick retina as revealed by the size and density of neurons in the ganglion cell layer. J Comp Neurol 195:643-657.

Fawcett JP, Aloyz R, McLean JH, Pareek S, Miller FD, McPherson PS, 
Murphy RA (1997) Detection of brain-derived neurotrophic factor in a vesicular fraction of brain synaptosomes. J Biol Chem 272:8837-8840.

Ferguson IA, Schweitzer JB, Johnson Jr EM (1990) Basic fibroblast growth factor: receptor-mediated internalization, metabolism, and anterograde transport in retinal ganglion cells J Neurosci 10:2176-2189.

Frade JM, Rodriguez-Tebar A, Barde YA (1996) Induction of cell death by endogenous nerve growth factor through its p75 receptor. Nature 383:166-168.

French PW, Jeffrey PL (1986) Partial characterization of chicken Thy-1 glycoprotein by monoclonal antibodies. J Neurosci Res 16:479-489.

Gaese F, Kolbeck R, Barde Y-A (1994) Sensory ganglia require neurotrophin-3 early in development. Development 120:1613-1619.

Garner AS, Menegay HJ, Boeshore KL, Xie X-Y, Voci JM, Johnson JE, Large TH (1996) Expression of trkB receptor isoforms in the developing avian visual system. J Neurosci 16:1740-1752.

Godement P, Vanselow J, Thanos S, Bonhoeffer F (1987) A study in developing visual systems with a new method of staining neurons and their processes in fixed tissue. Development 101:697-713.

Gunther EC, von Bartheld C, Goodman L, Bothwell M (1996) BDNF secretion is mediated by pertussis-toxin sensitive G-protein. Soc Neurosci Abstr 22:301.

Hallböök F, Bäckström A, Kullander K, Ebendal T (1996) Expression of neurotrophins and trk receptors in the avian retina. J Comp Neurol 364:664-676.

Hamburger V, Hamilton H (1951) A series of normal stages in the development of the chick embryo. J Morphol 88:49-92.

Hammerschlag R, Stone GC (1982) Membrane delivery by fast axonal transport. Trends Neurosci 5:12-15.

Hammerschlag R, Stone GC, Bolen FA, Lindsey JD, Ellisman MH (1982) Evidence that all newly synthesized proteins destined for axonal transport pass through the Golgi apparatus. J Cell Biol 93:568-575.

Hansson HA, Rozell B, Skottner A (1987) Rapid axoplasmic transport of insulin-like growth factor I in the sciatic nerve of adult rats. Cell Tissue Res 247:241-247.

Hendry IA, Stöckel K, Thoenen H, Iversen LL (1974) The retrograde axonal transport of nerve growth factor. Brain Res 68:103-121.

Herzog KH, von Bartheld CS (1998) Contributions of the optic tectum and the retina as sources of brain-derived neurotrophic factor for retinal ganglion cells in the chick embryo. J Neurosci 18:2891-2906.

Herzog KH, Bailey K, Barde Y-A (1994) Expression of the BDNF gene in the developing visual system of the chick. Development 120:1643-1649.

Heymach Jr JV, Barres BA (1997) Neurotrophins moving forward. Nature 389:789-791.

Holstege JC, Jongen JL, Kennis JH, van Rooyen-Boot AA, Vecht CJ (1998) Immunocytochemical localization of GDNF in primary afferents of the lumbar dorsal horn. NeuroReport 9:2893-2897.

Hoyle GW, Mercer EH, Palmiter RD, Brinster RL (1993) Expression of NGF in sympathetic neurons leads to excessive axon outgrowth from ganglia but decreased terminal innervation within tissues. Neuron 10:1019-1034.

Hunt SP, Brecha N (1984) The avian optic tectum: a synthesis of morphology and biochemistry. In: Comparative neurology of the optic tectum (Vanegas H, ed), pp 619-648. New York: Plenum.

Ibáñez CF (1996) Neurotrophin-4: the odd one out in the neurotrophin family. Neurochem Res 21:787-793.

Johnson Jr EM, Andres RY, Bradshaw RA (1978) Characterization of the retrograde transport of nerve growth factor (NGF) using high specific activity [ $\left.{ }^{125} \mathrm{I}\right]$ NGF. Brain Res 150:319-331.

Johnson Jr EM, Taniuchi M, Clark HB, Springer JE, Koh S, Tayrien MW, Loy R (1987) Demonstration of the retrograde transport of nerve growth factor (NGF) receptor in the peripheral and central nervous system. J Neurosci 7:923-929.

Johnson F, Hohmann SE, DiStefano PS, Bottjer SW (1997) Neurotrophins suppress apoptosis induced by deafferentation of an avian motorcortical region. J Neurosci 17:2101-2111.

Jungbluth S, Bailey K, Barde Y-A (1994) Purification and characterization of a brain-derived neurotrophic factor/neurotrophin-3 (BDNF/ NT-3) heterodimer. Eur J Biochem 221:677-685.

Kang HJ, Schuman EM (1995) Long-lasting enhancement of synaptic transmission in the adult hippocampus. Science 267:1658-1662.

Karlsson M, Hallböök F (1998) Kainic acid, tetrodotoxin and light modulate expression of brain-derived neurotrophic factor in developing avian retinal ganglion cells and their tectal target. Neuroscience 83:137-150.

Kiss J, Shooter EM, Patel AJ (1993) A low-affinity nerve growth factor receptor antibody is internalized and retrogradely transported selectively into cholinergic neurons of the rat basal forebrain. Neuroscience 57:297-305.

LaVail JH, Cowan MW (1971) The development of the chick optic tectum. I. Normal morphology and cytoarchitectonic development. Brain Res 28:391-419.

LaVail JH, Margolis TP (1987) The anterograde axonal transport of wheat germ agglutinin as a model for transcellular transport in neurons. Neurol Neurobiol 25:311-326.

Lefcort F, Clary DO, Rusoff AC, Reichardt LF (1996) Inhibition of the NT-3 receptor trkC, early in chick embryogenesis, results in severe reductions in multiple neuronal subpopulations in the dorsal root ganglia. J Neurosci 16:3704-3713.

Levine ES, Dreyfus CF, Black IB, Plummer MR (1995) Brain-derived neurotrophic factor rapidly enhances neurotransmission in hippocampal neurons via postsynaptic tyrosine kinase receptors. Proc Natl Acad Sci USA 92:8074-8077.

Linden R (1994) The survival of developing neurons. A review of afferent control. Neuroscience 58:671-682.

Lindholm D, Castrén E, Tsoulfas P, Kolbeck R, da Penha Berzaghi M, Leingärtner A, Heisenberg C-P, Tesarollo L, Parada LF, Thoenen H (1993) Neurotrophin-3 induced by tri-iodothyronine in cerebellar granule cells promotes Purkinje cell differentiation. J Cell Biol 122:443-450.

Lindholm D, Castrén E, Berzaghi M, Blöchl A, Thoenen H (1994) Activity-dependent and hormonal regulation of neurotrophin mRNA levels in the brain-implications for neuronal plasticity. J Neurobiol 25:1362-1372.

Lohof AM, Ip NY, Poo MM (1993) Potentiation of developing neuromuscular synapses by the neurotrophins NT-3 and BDNF. Nature 363:350-353.

Lunn ER, Brown MC, Perry VH (1990) The pattern of axonal degeneration in the peripheral nervous system varies with different types of lesion. Neuroscience 35:157-165.

Maisonpierre PC, Belluscio L, Conover JC, Yancopoulos GD (1992) Gene sequence of chicken BDNF and NT-3. DNA Seq 3:49-54.

McAllister AK, Katz LC, Lo DC (1999) Neurotrophins and synaptic plasticity. Annu Rev Neurosci 22:295-318.

Michael GJ, Averill S, Nitkunan A, Rattray M, Bennett DL, Yan Q, Priestley JV (1997) Nerve growth factor treatment increases brainderived neurotrophic factor selectively in TrkA-expressing dorsal root ganglion cells and in their central terminations within the spinal cord. J Neurosci 17:8476-8490.

Oppenheim RW (1996) The concept of uptake and retrograde transport of neurotrophic molecules during development: history and present status. Neurochem Res 21:769-777.

Purves D (1988) Body and brain. Cambridge, MA: Harvard UP.

Rager GH (1980) Development of the retino-tectal projection in the chicken. Adv Anat Embryol Cell Biol 63:1-92.

Reiner A, Brecha N, Karten HJ (1979) A specific projection of retinal displaced ganglion cells to the nucleus of the basal optic root in the chicken. Neuroscience 4:1679-1688.

Smith MA, Zang LX, Lyons WE, Mamounas LA (1997) Anterograde transport of endogenous brain-derived neurotrophic factor in hippocampal mossy fibers. NeuroReport 8:1829-1834.

Snider WD (1994) Functions of the neurotrophins during nervous system development: what the knockouts are teaching us. Cell 77:627-638.

Snider WD, Lichtman JW (1996) Are neurotrophins synaptotrophins? Mol Cell Neurosci 7:433-442.

Tanaka H, Agata A, Obata K (1989) A new membrane antigen revealed by monoclonal antibodies is associated with motoneuron axonal pathways. Dev Biol 132:419-435.

Taniuchi M, Johnson Jr EM (1985) Characterization of the binding properties and retrograde axonal transport of a monoclonal antibody directed against the rat nerve growth factor receptor. J Cell Biol 101:1100-1106.

Thoenen H (1995) Neurotrophins and synaptic plasticity. Science 270:593-598.

Vale RD, Shooter EM (1985) Assaying binding of nerve growth factor to cell surface receptors. Methods Enzymol 109:21-39.

von Bartheld CS (1996) Identification of the receptors which bind the 
neurotrophins BDNF and NT-3 during retrograde and anterograde axonal transport. Soc Neurosci Abstr 22:1002.

von Bartheld CS (1997) Anterograde transport of endogenous NT-3 from the retina to the optic tectum. Soc Neurosci Abstr 23:2244.

von Bartheld CS (1998a) Neurotrophins in the developing and regenerating visual system. Invited review. Histol Histopathol 13:437-459.

von Bartheld CS (1998b) Radio-iodination of neurotrophins and their delivery in vivo: advantages of membrane filtration and the use of disposable syringes. J Neurosci Methods 79:207-215.

von Bartheld CS, Cunningham DE, Rubel EW (1990) Neuronal tracing with DiI: decalcification, cryosectioning, and photoconversion for light and electron microscopic analysis. J Histochem Cytochem 38:725-733.

von Bartheld CS, Heuer JG, Bothwell M (1991) Expression of nerve growth factor (NGF) receptors in the brain and retina of chick embryos: comparison with cholinergic development. J Comp Neurol 310:103-129.

von Bartheld CS, Schober A, Kinoshita Y, Williams R, Ebendal T, Bothwell M (1995) Noradrenergic neurons in the locus coeruleus of birds express trkA, transport NGF, and respond to NGF. J Neurosci 15:2225-2239.

von Bartheld CS, Byers MR, Williams R, Bothwell M (1996a) Anterograde transport and axo-dendritic transfer of neurotrophins in the developing visual system. Nature 379:830-833.

von Bartheld CS, Williams R, Lefcort F, Clary DO, Reichardt LF, Bothwell M (1996b) Retrograde transport of neurotrophins from the eye to the brain in chick embryos: roles of the p $75^{\mathrm{NTR}}$ and trkB receptors. J Neurosci 16:2995-3008.

Wang XX, Butowt R, von Bartheld CS (1999) Mechanisms of the release of NT-3 from presynaptic axon terminals. Soc Neurosci Abstr 25:1786.

Wayne DB, Heaton MB (1990) The ontogeny of specific retrograde transport of nerve growth factor by motoneurons of the brainstem and spinal cord. Dev Biol 138:484-498.

Wu K, Xu J-1, Suen PC, Levine E, Huang Yy, Mount HTJ, Lin Sy, Black IB (1996) Functional trkB neurotrophin receptors are intrinsic components of the adult brain postsynaptic density. Mol Brain Res 43:286-290.

Yan Q, Rosenfeld RD, Matheson CR, Hawkins N, Lopez OT, Bennett L, Welcher AA (1997) Expression of brain-derived neurotrophic factor protein in the adult rat central nervous system. Neuroscience 78:431-448.

Zhou X-F, Rush RA (1993) Localization of neurotrophin-3-like immunoreactivity in peripheral tissues of the rat. Brain Res 621:189-199.

Zhou X-F, Rush RA (1996) Endogenous brain-derived neurotrophic factor is anterogradely transported in primary sensory neurons. Neuroscience 74:945-951.

Zhou X-F, Zettler C, Rush RA (1994) An improved procedure for the immunohistochemical localization of nerve growth factor-like immunoreactivity. J Neurosci Methods 54:95-102. 